\title{
Berättelser om syskonjordbruk
}

I det inledande kapitlet nämnde jag att "syskonjordbruk" inte var ett begrepp som användes i samtiden och att en undersökning av dem skulle kräva en kombination av olika angreppssätt och material. Hittills har jag bland annat använt statliga utredningar, statistik om ägandeformer och folkräkningsmaterial, vilka sammantaget tecknat en mångfacetterad bild av syskongårdarnas antal, struktur och förutsättningar. Men flera viktiga perspektiv har saknats. För det första har det källmaterial jag använt hittills betraktat hushållen utifrån. Det har medfört att fokus legat på observerbara och mätbara faktorer: hushållsmedlemmar, åldrar, ägandeförhållanden, jordbrukets tekniska status och så vidare. Förhållandet har gjort det möjligt att besvara frågor om förekomst och sammansättning, men inte hur de berörda syskonen själva förstått sin situation och motiverat sina livsval. Vilka valmöjligheter har funnits, vilka uppoffringar har gjorts och vem har gjort valen? Har etableringen av syskonjordbruket upplevts som ett strategiskt val - och vems strategi rör det sig i så fall om? För det andra har tonvikten legat på synkrona analyser av exempelvis hushållsstruktur eller arvspraxis vid en rad tidpunkter, vilket medför en risk för att syskonjordbruken framstår som statiska. Hur många som ingick i ett hushåll vid ett visst tillfälle är en viktig upplysning, men den säger föga om varför just dessa hushåll utvecklades till att bli syskonhushåll. Går det att skönja mönster i hur de uppstod? Finns det några särskilda faktorer som har gynnat tillkomsten?

I detta sista empiriska kapitel söker jag svar på dessa frågor genom att anlägga ett inifrånperspektiv på ett begränsat antal syskonjordbruk. I vissa avseenden behandlar jag likartade frågeställningar som i de föregående kapitlen, men mitt huvudsakliga syfte är inte 
att testa mina resultat mot ett annat material, utan att med hjälp av uppgifter som inte återfinns i offentliga arkiv blottlägga andra sammanhang och beroenden.

\section{Att söka, finna och skapa material}

Med ambitionen att teckna ett inifrånperspektiv följer att det som i första hand måste eftersträvas är uppgifter från de berörda syskonen själva. Att finna sådana källor är lättare sagt än gjort. När syskon bott tillsammans har det inte funnits någon större anledning att kommunicera skriftligen, och även om skrivet källmaterial har samlats på en släktgård är risken stor att det har försvunnit när syskonen dött och egendom gått i arv till avlägsna släktingar. En sökning i folkminnesmaterial om släkt och familj ger heller inte mer än några enstaka omnämnanden av syskonjordbruk. ${ }^{466}$ Levnadsteckningar eller bondedagböcker som beskriver vardagslivet på gården skulle kunna vara en användbar källa, men förutom svårigheten att hitta sådana från syskonjordbruk härrör de dagböcker som insamlats i olika nationella och regionala initiativ från tiden före sekelskiftet $1900 .{ }^{467}$ Det enda undantag jag funnit är en omarbetad dagbok av Verner Ohlin, som var verksam som författare men också bodde och deltog i arbetet på ett mindre jordbruk i södra Småland tillsammans med två av sina syskon. Ohlins bok erbjuder förvisso en intressant skildring, men den begränsar sig till ett enda år (1980) och lägger tonvikten vid bondelivets årscykel. ${ }^{468}$

Bristen på skriftligt material är således tydlig. Det som återstår är att försöka komma åt uppgifter som inte blivit nedskrivna, och jag har därför eftersökt informanter som kunnat ge uppgifter om verkliga syskonjordbruk. Intervjupersoner har sökts på två sätt: ett upprop i tidskriften Land samt efterlysningar i ett par lokalradiostationer. ${ }^{469} \mathrm{I}$ båda fallen tydliggjordes att det jag sökte var hushåll där minst två syskon bott tillsammans och drivit jordbruk ihop. Drygt 70 svar inkom, varav 29 valdes ut. Inledningsvis var förhoppningen att komma i kontakt med personer som själva varit syskonjordbrukare, men för ett sådant syfte visade sig undersökningen vara genomförd 
minst tjugo år för sent. Som framgick i kapitel 4 minskade antalet syskonjordbruk snabbt mot slutet av 1900-talet och de syskon som återstod vid seklets slut var i de flesta fall över 65 år. Endast en ringa del av 1900-talets syskonjordbrukare är fortfarande i livet, och de har nått en hög ålder. Av de utvalda informanterna har bara sex drivit jordbruk med sina syskon, den yngsta av dem var vid intervjun 85 år gammal och den äldsta 91 år. ${ }^{470}$ Bland de inkomna svaren finns emellertid även ett stort antal personer som är nära släktingar eller på annat sätt närstående till avlidna syskonjordbrukare. Den vanligaste relationen är att de jordbrukande syskonen var informanternas morbröder och farbröder, mostrar och fastrar.

Totalt omfattar denna delstudie 29 intervjuer genomförda mellan oktober 2014 och december 2015. Informanterna har varit spridda över hela landet och intervjuer har genomförts från Skåne i söder till Västerbotten i norr, från Bohuslän i väster till Gotland i öster. Intervjuerna tog i regel mellan två och fyra timmar att genomföra och spelades, med något undantag, in. Vid merparten av samtalen deltog enbart en informant. ${ }^{411}$ Jag följde en i förväg upprättad frågemall och informanterna fick samma frågor, om än inte alltid i samma ordning. Den grundläggande frågeställningen var varför syskonjordbruken etablerades, men för att få en bredare bild av förhållandena frågade jag även om föräldrar, syskon som flyttat, boendeförhållanden, arbetsuppgifter på gården, arbete utanför gården, syskonens eventuella kärleksrelationer och äktenskapsplaner, föreningsliv och social samvaro samt gården och jordbruket.

En undersökning av detta slag aktualiserar inte sällan etiska problem om hur de intervjuades integritet och anonymitet bäst skyddas. Intervjuerna har rört ämnen som ibland uppfattats som känsliga och intervjupersonerna kan under samtalets gång ha öppnat sig mer än vad de från början tänkt. ${ }^{472}$ Att huvudpersonerna i de flesta intervjuer inte var informanterna själva innebär dessutom att andra närstående kan ha åsikter om såväl lämpligheten i intervjun som dess innehåll. ${ }^{473}$ En del syskonjordbruk skulle kunna identifieras enbart utifrån en ungefärlig ortsbestämning och vissa årtal. För att förhindra det använder jag genomgående fingerade namn och anger bara länet eller landskapet. Jag återger några enstaka 
citat från intervjuerna och ett antal längre intervjureferat. Dessa syftar till att lyfta fram en eller flera aspekter från intervjun och därmed renodla vissa sakförhållanden. I referaten har jag i de flesta fall inledningsvis återgett informanten och dennes relation till de berörda syskonen.

\section{Intervjuns möjligheter och brister}

Hur muntlig historia bör analyseras och bedömas har debatterats flitigt inom historieforskningen under flera decennier. ${ }^{474}$ Grundfrågan är vilken tillförlitlighet informanternas uppgifter bör anses ha. Vad gäller de genomförda intervjuerna finns det i första hand skäl att diskutera tre problem.

För det första har det inte gått att uppbåda särskilt många informanter som själva varit syskonjordbrukare, utan de flesta var släktingar till sådana. Redan här har delstudiens ambition om ett inifrånperspektiv i strikt mening gått om intet och det är möjligt att de syskon som står i fokus för berättelserna själva skulle ha gett en annan bild eller betonat andra faktorer och skeenden. Utan att negligera denna invändning måste dock det valda tillvägagångssättet ställas mot alternativen. De syskon samtalen kretsat kring är döda - faktum är att en mycket stor andel av de intervjuade syskonbarnen själva är pensionärer, i vissa fall i 9o-årsåldern. Inom något decennium är många av dem sannolikt borta och därmed den enda direkta kopplingen till 1900-talets syskonjordbruk. Vid urvalet av informanter har jag eftersträvat personer som haft en lång och nära relation med de berörda syskonen. Enbart släktskap behöver inte innebära detaljkännedom om förhållandena i hushållet, om kontakten har varit begränsad till årliga träffar, födelsedagar eller julhelger. För att säkerställa en viss nivå av tillförlitlighet har jag därför tillämpat ett närhetskriterium för informanterna: de ska ha tillbringat en del av sin uppväxt i hushållet, återkommande vistats där under längre perioder (exempelvis om somrarna) eller bott $\mathrm{i}$ direkt anslutning och därtill umgåtts flitigt med dess medlemmar. ${ }^{475}$ Samtliga informanter är således primärkällor, deras uppgifter bygger på egna upplevelser. ${ }^{476}$ Att det för de flesta informanter inte varit 
den egna levnadsberättelsen som stått i fokus kan också ha inneburit vissa fördelar, exempelvis har risken att skönmåla sin egen betydelse inte varit så överhängande. ${ }^{477}$

För det andra går det inte att komma ifrån att de händelser som återges i intervjuerna i många fall ligger flera decennier tillbaka i tiden. Eftersom en källa normalt bedöms ha större trovärdighet ju mer samtida med händelsen den är innebär det långa tidsavståndet ett problem. Minnen faller bort och förbleknar. Det är dock inte en unik situation för denna studie. I en diskussion om källkritiska aspekter av att arbeta med muntliga källor framhåller Malin Thor att det långa tidsavståndet mellan händelsen och källans tillblivelse (intervjun) är ett kännetecken för muntlig historia. ${ }^{478}$ Alla hågkomster försvinner inte heller. Paul Thompson menar att informantens intressen spelar en avgörande roll för vad som blir ihågkommet; vi minns det vi har upplevt som intressant. ${ }^{479}$ Samtidigt är de minnen som återges inte oberörda av tidens gång, oavsett hur lång eller kort tid som har passerat. Ingar Kaldal argumenterar för att alla minnen - barndomens såväl som gårdagens - bör betraktas som processer. De är varken något som uppstår vid återberättandet eller som enbart handlar om det som en gång hände - "de blir till etter hvert" ${ }^{480}$ Det är inte troligt att informanterna kan återge alla detaljer i en enskild händelse, men frågorna under intervjun har inte i första hand kretsat kring sådana utan kring större skeenden, sociala relationer och relativt varaktiga förhållanden i de intervjuades direkta närhet. ${ }^{481}$ Dessa sakförhållanden har därtill haft direkt betydelse för de intervjuade, inte minst eftersom det ofta var de som i slutändan efterträdde syskonen som fastighetsägare. Jag har i några fall kontrollerat informanternas uppgifter om ägandeförhållanden mot framför allt fastighetsböcker, utan att finna några avgörande avvikelser. Någon möjlighet att kontrollera alla faktauppgifter finns emellertid inte. Det visar att muntligt källmaterial behövs: det ger uppgifter av ett slag som normalt inte återfinns i arkiven. ${ }^{482}$

För det tredje finns ett potentiellt problem med gruppen informanter som sådan. Gemensamt för dem är att de har besvarat ett upprop och det finns risk att de hörde av sig eftersom de främst har goda minnen av syskonjordbruk. Det är mindre troligt att 
informanter som kunnat berätta om bittra familjefejder alls skulle höra av sig. Det kan således finnas en tendens att den bild av syskonen och deras liv som framträder i informanternas berättelser är något ljusare än vad den hade varit om jag hade kunnat studera exempelvis alla syskonjordbruk inom ett visst område. Också i enskilda intervjuer finns en risk att de ljusa minnena tar överhanden medan kontroverser och konflikter underdrivs. ${ }^{483}$ En förklaring till detta kan vara att minnena verkar på olika sätt. Ingar Kaldal talar om att minnen dels beskriver och ger uppgifter om något som har hänt, dels skapas och formas i de sammanhang där de uppstår och dels ofta brukas så att de själva präglar och formar något. ${ }^{484}$ I intervjuerna är det huvudsakligen den första betydelsen som är målet: minnena ger uppgifter om hur saker och ting var och hur de upplevdes. Men det går inte att bortse från Kaldals andra aspekter. Minnen formas starkt av de sammanhang - rumsliga, tidsliga och kulturella - som de uppstår i. För de informanter som tillbringade sin barndoms lyckligaste somrar hos sina fastrar och farbröder är det således lätt att själva minnet ges en ljusare inramning. Flera intervjuer vittnar visserligen om relativt ansträngda sociala relationer som i något fall eskalerat till regelrätta konflikter, men vanligare är att sådana oenigheter inte framkom. Materialet har således en viss tendens som är svår att parera och som det därför är viktigt att vara medveten om.

\section{De undersökta syskonjordbruken}

I 27 av de 29 intervjuerna berättade informanterna om ett enskilt syskonjordbruk, i de resterande två vardera två syskonjordbruk i den närmaste släktkretsen. ${ }^{485}$ Totalt rörde intervjuerna alltså 31 unika syskonjordbruk. Dessa är spridda över landet och utgör en brett sammansatt grupp med mycket varierande förutsättningar, från småbrukare i skogsbygd till mindre gods i slättlandskap. ${ }^{486}$ Hälften av dem, sexton hushåll, omfattade två syskon. Sju hushåll omfattade tre syskon, fem hushåll fyra, två hushåll fem och ett hela sex syskon. Antalet syskon avser i detta sammanhang enbart de som bodde kvar. Eftersom det i flertalet familjer även 
funnits syskon som lämnat föräldragården var syskonskarorna i de flesta fall större. Av de 31 undersökta familjerna stannade samtliga syskon kvar på gården i åtta. ${ }^{487}$ Att en i syskonskaran flyttade ut förekom i sex familjer, i sju andra flyttade två och i de återstående tio familjerna flyttade mellan tre och sju personer. Det vanligaste var med andra ord att åtminstone någon lämnade hemmet. Däremot utgjorde de kvarboende oftast merparten av syskonskaran; enbart i sex av 31 fall fanns fler utflyttande än kvarboende. Syskonhushållet var med andra ord en angelägenhet för större delen av syskonskaran.

Det är inte helt enkelt att en gång för alla slå fast hushållets sammansättning. Syskon kunde flytta fram och tillbaka, dödsfall medförde ibland rockader och äktenskap kunde ingås påfallande sent. En manlig slagsida framträder dock: av runt 90 syskonjordbrukare var knappt 60 män och drygt 30 kvinnor. Däremot var det ovanligt med helt enkönade sammansättningar. Totalt fanns bara sex sådana, samtliga bestående av män. I tabell 5.1 har syskonskarorna periodiserats med utgångspunkt i det äldsta syskonets födelsedecennium.

Tabell 5.1 Äldsta syskonets födelsedecennium för 31 syskonjordbruk. $\begin{array}{ccccccccc} & 1870 & 1880 & 1890 & 1900 & 1910 & 1920 & 1930 & 1940 \\ \text { Antal } & 1 & 2 & 6 & 10 & 7 & 2 & 2 & 1\end{array}$

De flesta syskonen var födda decennierna runt sekelskiftet 1900 och de tillträdde vanligen jordbruket under 1930-, 1940- eller 1950-talet. Att det inte finns fler exempel på syskon födda före 1890-talet är sannolikt en följd av tidsavståndet: det råder av naturliga skäl brist på levande personer som haft insikt i sådana hushåll. ${ }^{488} \mathrm{De}$ få exemplen på syskon födda efter 1910-talet kan emellertid inte förklaras på liknande sätt. Som framgick i förra kapitlet blev syskonjordbruken visserligen färre under seklets senare del, men de var ännu på 1970-talet inte ovanliga. Att jordbruk som var aktiva under 1900-talets senare decennier är underrepresenterade kan naturligtvis ha flera skäl, men det får till följd att intervjumaterialet i första hand speglar syskonjordbruk cirka 1920-1970. Det var 
emellertid under denna period som syskonjordbruken var som flest och den kronologiska tyngdpunkten behöver därför inte vara ett problem.

\section{Arbete, jordbruk och hushåll}

Jordbruket har spelat huvudrollen i samtliga berörda hushåll, men förutsättningarna varierade. Det finns inget jordbruk med specialinriktning i intervjumaterialet, de var utan undantag blandjordbruk med både växtodling och djurhållning. Mjölkproduktionen utgjorde i de flesta fall jordbrukets ryggrad, men besättningarna varierade från 3-4 kor upp till stora enheter som redan under 1950-talet hade över 20 stycken. Vanligast var att antalet kor låg mellan fem och tio, vilket kan sägas motsvara en normal mjölkdjursbesättning under decennierna vid seklets mitt. ${ }^{489}$ Därtill fanns givetvis andra djur - hästar, får, grisar och höns - på de flesta enheter. Arealmässigt uppvisar de ingående jordbruken stora variationer, från småbruk med 3-4 hektar åker till stora gårdar med över 20 hektar. I ett fall drev tre syskon tillsammans ett mindre gods på drygt 100 hektar åker och en mjölkbesättning om drygt 30 kor i mitten av 1950-talet. Formatet till trots förde syskonen inget överklassliv medan anställda skötte gården, alla tre var djupt involverade i driften och deltog fullt ut i jordbruksarbetet. ${ }^{490}$ Att intervjumaterialet omfattar familjer och jordbruk med vitt skilda förutsättningar gör det stundtals tveksamt att tala om dem som en enhetlig grupp. Variationerna understryker å andra sidan den mångskiftande bild av syskonjordbruken som utmejslades i förra kapitlet.

Flertalet informanter uppgav att hushållet inte hade några viktiga intäkter vid sidan om jordbruket. I nio fall förekom dock arbete utanför gården. Det absolut vanligaste var att några bröder utförde skogsarbete åt andra. ${ }^{491}$ Arbetet pågick oftast under vinterhalvåret, när jordbruket tog mindre tid i anspråk. I tre fall arbetade ett syskon som lantbrevbärare, någon var iväg i perioder på järnvägs- eller vägbyggen, en hade en mindre trädgårdsverksamhet och utförde dessutom uppdrag åt kommunen, en arbetade deltid som lokalvårdare, en sysslade med olika slags hantverk, några tjänstgjorde 
tidvis inom sjukvården. På två gårdar sysslade ett par av syskonen med såg- eller snickeriverksamhet, vilket i det ena fallet upptog merparten av tiden för en bror på gården som därför bara deltog i jordbruksarbetet under de största arbetstopparna. ${ }^{492}$ Det är dock det enda exemplet på att ett syskon mer eller mindre frikopplats från jordbruksarbetet till förmån för en sidoverksamhet. Jordbruket var navet i tillvaron, men att utomgårdsarbeten förekom illustrerar väl den diversifierade jordbrukartillvaro som kännetecknade många småbruk under några decennier vid 1900-talets mitt. Syskonjordbruken var lika lite som ordinära familjejordbruk statiska och hushållets medlemmar kunde syssla med lite av varje beroende på gårdens förutsättningar.

Det var i första hand bröder som arbetade utanför gården. Med utgångspunkt i minnesuppteckningar från familjejordbruk menar Anders Perlinge att det på enheter som i sig inte gav tillräckliga inkomster fanns en strategi att frikoppla mannen till sådana arbeten, vilket gjorde att kvinnorna fick ta större ansvar för det dagliga arbetet på gården. Perlinge påpekar att även kvinnor kunde arbeta utanför gården, men då vanligtvis på mindre deltidsarbeten som gjorde att de kunde vara till hands när jordbruket så krävde. ${ }^{493}$ Denna bild stämmer väl överens med situationen på jordbruken i intervjumaterialet. Systrarna arbetade i mycket liten utsträckning utanför hemmet, och då på deltid som lokalvårdare eller inom vården. ${ }^{494}$ Till viss del kunde dock förhållandena skifta över tid. En kvinna som senare drev ett jordbruk med sin bror hade arbetat heltid vid en fabrik i samhället i yngre år, medan föräldrarna ännu levde. När föräldrarna blev äldre slutade hon för att istället sköta om dem och hushållssysslorna på gården. ${ }^{495}$ Ett mer allmänt åtagande som halvt låg utanför gården och som ofta föll på kvinnornas lott var att sälja gårdens produkter, särskilt ägg. På en gård som producerade 15-20 kilo ägg per vecka såldes äggen av den syster som förestod hushållet och "äggapengarna" användes som hushållskassa. ${ }^{496}$ 


\section{Mekanisering och framtidsperspektiv}

I kapitel 4 diskuterade jag graden av mekanisering på syskonjordbruken med utgångspunkt i 1944 års jordbruksräkning. Det visade sig att de inte skilde sig på något avgörande sätt från andra jordbruk. Den stora vattendelaren var jordbrukets storlek, inte huruvida det var ett syskonjordbruk eller inte. Höll syskonjordbruken jämna steg med den allmänna mekaniseringen också efter seklets mitt? Decennierna omedelbart efter andra världskriget innebar en snabb och omvälvande mekanisering av det svenska jordbruket, vilket gick hand i hand med den statligt styrda storleksrationaliseringen. Under ett fåtal decennier förändrades jordbruket kraftigt och hur detta hanterades på varje enskild enhet kunde få stora effekter. Kan dessa nya förutsättningar förklara syskonjordbrukens svagare ställning under 1900-talets senare del? Intervjuerna är inte något idealt sätt att studera den tekniska utvecklingen: dels är representativiteten oklar, dels kunde informanterna inte alltid återge tekniska förhållanden på detaljnivå. Det är dock möjligt att ge en översikt av hur de berörda gårdarna förhöll sig till de nya förutsättningarna.

Ur materialet går det att urskilja tre olika varianter. Den största gruppen kännetecknades av stagnation. Ifråga om tekniska förändringar rådde närmast stiltje och jordbruken drevs vidare på i princip samma sätt som under föregående generation. Flera jordbruk drevs långt in på 1990-talet utan vare sig traktor eller mjölkmaskin. Dessutom saknade gården ofta bil. Kännetecknande för denna kategori jordbruk var att den odlade arealen ofta var relativt liten (vanligen runt 5 hektar), syskonen oftast två och arbetsintensiteten mycket stor. Som ett exempel kan nämnas en gård med en bror och syster där jordbruket fram till mitten av 1960-talet drevs med en häst som dragdjur och där djurbesättningen aldrig uppgick till mer än 4-5 kor, några grisar och lite höns. Hushållet var i stor utsträckning självförsörjande. Någon bil införskaffades aldrig och även boendestandarden förblev densamma. Vid sidan av ett rum som sommartid användes av en utflyttad bror med familj var övervåningen i mangårdsbyggnaden oinredd och det saknades toalett. Mot slutet av 1950-talet började mer avlägset belägna åkrar planteras igen med gran. ${ }^{497}$ 
En nästan lika stor kategori syskonjordbruk utmärktes av anpassning till de nya förhållandena. De hängde någorlunda med sin tid. Elektrisk kraft drogs in, mjölkmaskin införskaffades på 1940-talet och traktorn gjorde entré under 1950-talet eller åtminstone vid 1960-talets början. Mjölkproduktionen utgjorde stommen i dessa gårdars ekonomi och besättningarna kunde uppgå till 10-12 kor. Den odlade arealen låg vanligen i spannet 5-15 hektar och förblev densamma över tid. Någon vilja att utöka arealen genom arrende tycks inte ha funnits. ${ }^{498}$ De flesta gårdarna i denna grupp var aktiva jordbruksenheter åtminstone in på 1970-talet.

Av de 31 syskonjordbruken kan 14 klassificeras som stagnerade och 13 som anpassade. De resterande fyra låg snarast i mekaniseringens framkant. De utmärktes av expansion och gjorde omfattande investeringar. Ett jordbruk med två bröder och två systrar införskaffade sin första traktor runt 1950 (en Ferguson-grålle) och sin andra 1957, varpå en av traktorerna regelmässigt byttes ut vart tredje år - alltid nytt, aldrig begagnat. Ladugården byggdes om på 1940-talet, mjölkmaskin installerades och i början av 1950-talet var djurbesättningen drygt 20 kor. Investeringarna fortsatte, bland annat tillkom ett nytt svinhus runt 1960. Vid sidan om gården arrenderades omkringliggande enheter och 1960 köpte syskonen grannfastigheten och lade den under gårdens drift. Lantbruket drevs så föredömligt att bröderna i mitten av 1960-talet fick ta emot ett stort jordbrukspris ur landshövdingens hand. ${ }^{499}$ De fyra expansiva enheterna utmärktes framför allt av sin storlek - de hade 20-30 hektar åker och stora mjölkbesättningar - men också av antalet vuxna på gården. På tre av enheterna fanns fyra syskon, på den fjärde två varav en hade familj.

Uppdelningen i stagnerade, anpassade och expansiva jordbruk antyder att syskonstrukturen i sig inte avgjorde mekaniseringsnivån. Mer rimligt är att knyta de olika handlingsmönstren till den allmänna jordbruksutvecklingen inom olika storleksgrupper. Bland syskonjordbruken fanns många som drevs på ålderdomligt vis, men det var ett allmänt drag hos det svenska jordbrukslandskapet vid denna tid. På samma sätt höll den expansiva gruppen jämna steg med utvecklingen för större jordbruksenheter. 


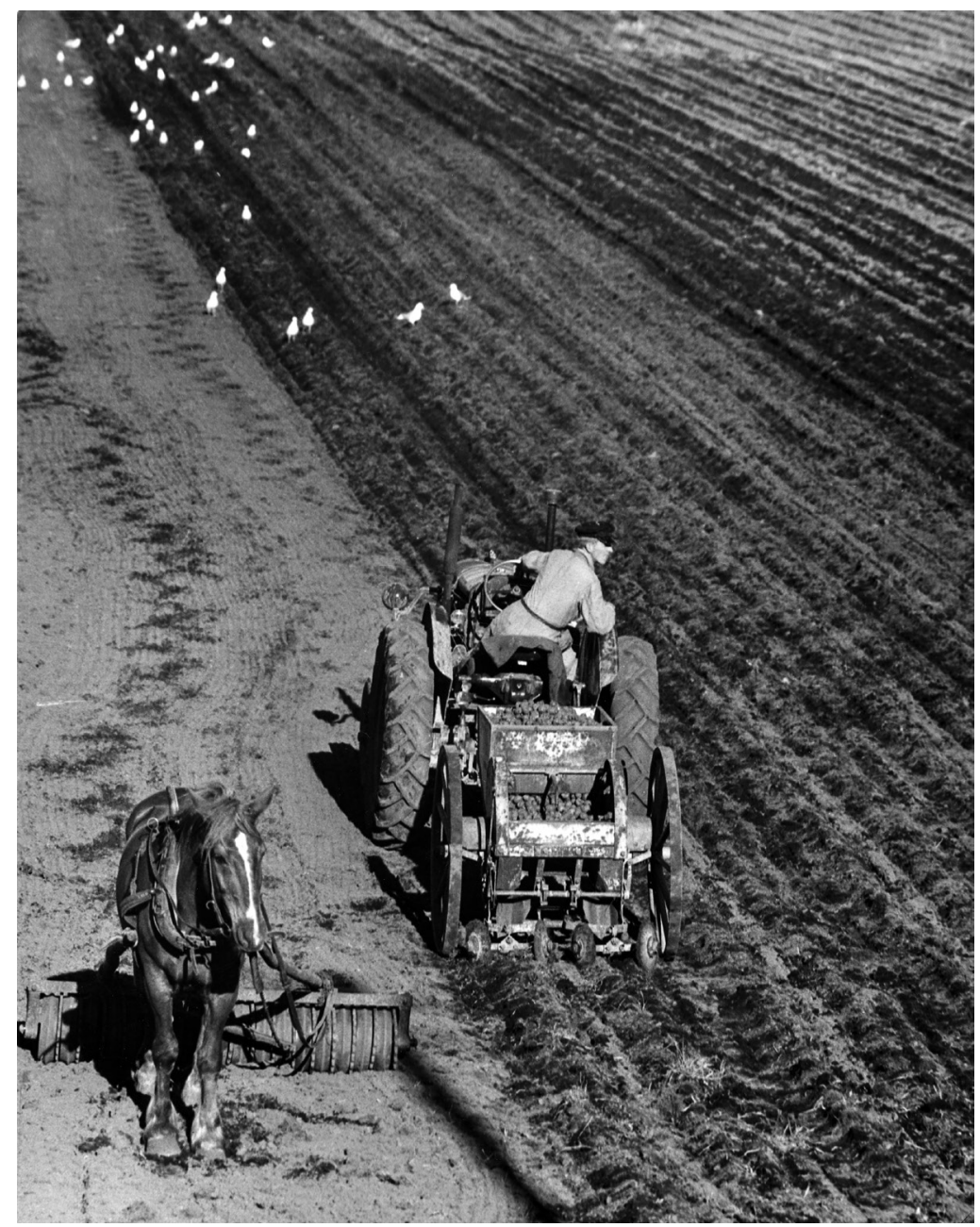

Traktorn ersatte under 1950-talet i allt större utsträckning hästen som dragkraft, och under en period kunde de användas parallellt. Traktorn drar potatissättaren, men ringvälten är ännu kopplad till häst. Blekinge, cirka 1950. Foto: Gunnar Lundh/Nordiska museet.

Kort sagt - syskonjordbruken följde i huvudsak den allmänna jordbruksutvecklingen. ${ }^{500}$ Därmed inte sagt att alla stora enheter blev expansiva och alla små rangerades ut. Det fanns mer oväntade handlingsmönster. En stor gård med många syskon födda under 1900-talets första decennium genomgick ingen nämnvärd 
mekanisering. Hästarna behölls som dragdjur och trots en stor mjölkbesättning introducerades aldrig maskinmjölkning. Istället sålde syskonen gården i slutet av 1950-talet och flyttade gemensamt till en villa i ett närliggande samhälle. ${ }^{501}$

En faktor som bör tas i beaktande i samband med frågan om mekanisering är gårdens framtidsperspektiv. Agrarsociologerna Clive Potter och Matt Lobley understryker i en analys av generationsväxlingar i brittiskt jordbruk under 1900-talet betydelsen av en tidigt identifierad efterträdare. Beroende på om en sådan fanns eller inte utvecklade brukarna olika handlingsmönster, särskilt ifråga om investeringar. En given efterträdare till gården ökade incitamenten att satsa för att "hänga med" och möjliggöra att enheten även framöver skulle vara bärkraftig. Var framtiden mer osäker minskade benägenheten att göra dyra investeringar. ${ }^{502}$ Det är också tänkbart att själva förekomsten av barn på gårdarna hade inverkan på mekaniseringstakten. Anders Perlinge driver i sin bok om bondeminnen tesen att mekanisering och elektrifiering av jordbruket delvis grundades i en önskan att låta barnen slippa tunga och farliga arbetsuppgifter. ${ }^{503}$

Kan avsaknad av barn och arvingar förklara den lägre mekaniseringsgraden på syskonjordbruken? Visserligen är inte närvaron av barn i jordbruket helt enkel att klarlägga - särskilt sommartid utökades flera av syskonhushållen när utflyttade syskon eller syskonbarn bodde och arbetade på gården - men permanent boende barn fanns på endast fem av de 31 jordbruken. Enligt Perlinges tes skulle incitamentet till förbättringar därmed vara lägre på många syskonjordbruk eftersom barn ofta saknades. Av de fem gårdarna med barn kan en hänföras till de stagnerande, två till de anpassade enheterna och två till de expansiva. Perlinges tes tycks således ha visst stöd. Med barn i bilden fanns dessutom en möjlig efterträdare, vilket inte var lika givet på de gårdar där det saknades barn. Det innebär dock inte att det där saknades förväntningar och tankar på att någon närstående skulle kunna överta gården. I ett par fall fanns en uttalad vilja att hålla gården i släkten, särskilt om den i flera generationer drivits av samma familj. ${ }^{504}$ I de fall något syskon flyttade ut, gifte sig och fick barn stod dessa i tur att överta gården, 
även om de långtifrån alltid erhöll en tydligt erkänd ställning som efterträdare. ${ }^{505}$ I brist även på lämpliga syskonbarn kunde det finnas ett annat alternativ. I tre av syskonhushållen bodde fosterbarn under perioder, och enligt informanterna fanns det hos syskonen förhoppningar om att kunna överföra gården på dem. ${ }^{506}$ Det är dock överlag svårt att finna någon tydlig korrelation mellan mekaniseringstakt och efterträdare. En möjlig anledning är att den snabba jordbruksomvandlingen gjorde framtiden oviss. För merparten av syskonjordbrukarna torde det med tiden ha stått klart att de utgjorde den sista jordbrukande generationen på gården.

Det osäkra framtidsperspektivet på flera gårdar hade sannolikt också viss betydelse för takten i jordbruksarbetet. Flertalet informanter vittnar om att syskonjordbruken var mycket arbetsintensiva och att syskonen i princip arbetade jämt. Några nämner dock att det fanns ett lugn $i$ arbetet. En informant som tillbringade mycket tid på gården hos sina mostrar och sin morbror menar att det hos dem rådde en mindre stressad stämning än på hans föräldrars större och mer mekaniserade jordbruk. Blev det regn fick de ta in höet en annan dag, det var inte hela världen. ${ }^{507}$ Kanske kan denna inställning kopplas till en lägre ambition vad gäller investeringar och framtidsperspektiv. Vetskapen att de själva sannolikt var de sista som skulle driva gården som ett jordbruk kan i kombination med att en given efterträdare saknades ha lett till en sådan mer avslappnad inställning.

\section{Arbetsfördelning}

Det finns mycket forskning om hur arbetsdelningen i jordbruket har fungerat och utvecklats, ofta med fokus på vilka uppgifter som har ansetts könsligt kodade och hur sådana uppfattningar har förändrats. ${ }^{508}$ Långtifrån alla informanter har kunnat ge fullödiga svar om hur olika arbetsuppgifter inom jordbruket och hushållet fördelats, men de flesta har kunnat redogöra för några övergripande skiljelinjer i arbetsfördelningen. Ansvaret för hästarna och så småningom traktorerna var en manlig angelägenhet. Det gällde både vid den dagliga omvårdnaden och när dragkraften skulle utnyttjas i 


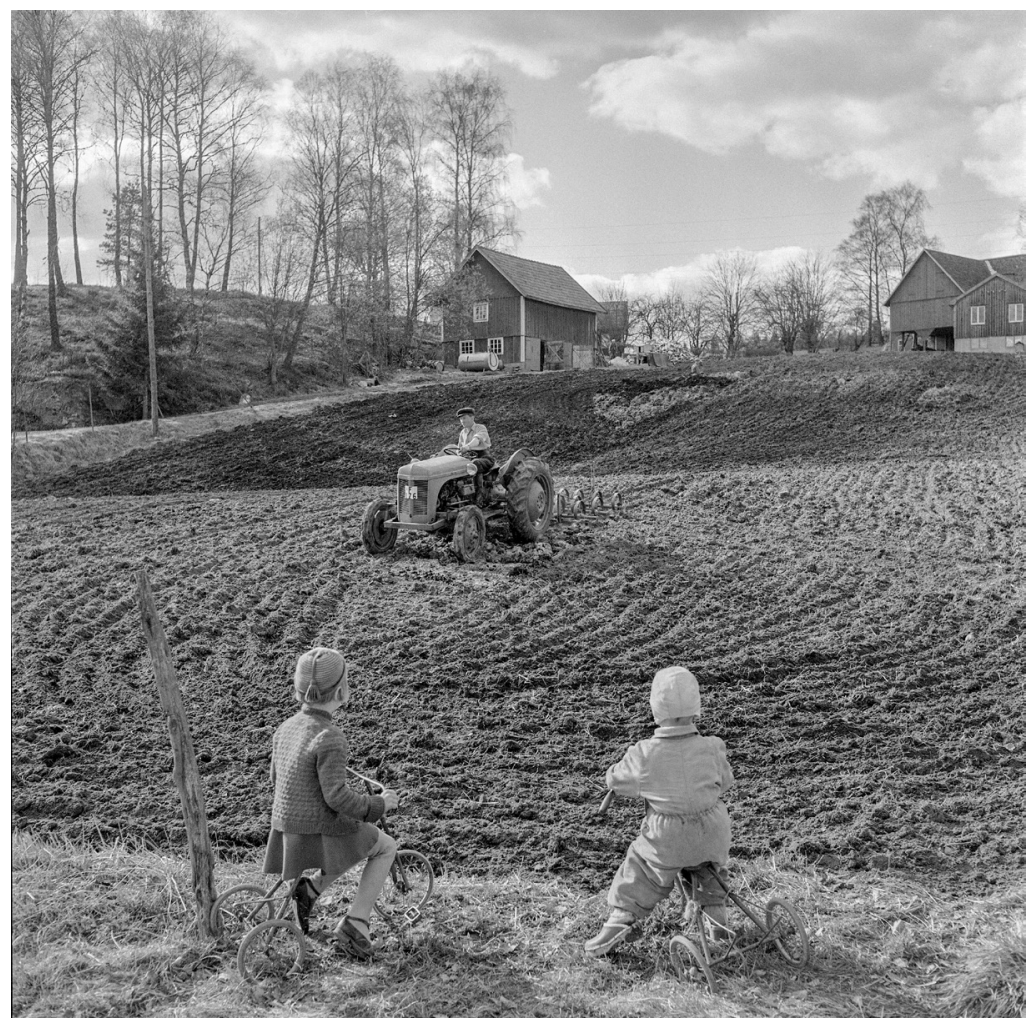

Utan möjliga efterträdare minskar viljan att investera i jordbruket. Vårbruk i Småland under nyfiket överinseende av kommande generationer. Foto: Erik Liljeroth/ Nordiska museet.

jordbruket. Till detta hörde också ansvaret för plog, harv och annan utrustning i anslutning till häst och traktor. Trädgården och det som odlades där var ofta en kvinnlig domän, även om det fanns enstaka män som intresserade sig för biodling eller olika typer av fruktträd och bärbuskar. ${ }^{509}$ Flera informanter såg en gräns mellan att män i huvudsak arbetade "ute" och kvinnor "inne": bröder hade som regel ansvar för åkrar och ängar, skog och stängsling, medan systrar skötte matlagning, tvätt och städning.

När det gäller ansvaret för djuren och särskilt korna går bilden mera isär, vilket stämmer väl med forskningsdiskussionen. Flera studier har visat att mjölkhanteringen under 1900-talets första hälft 
gick från att vara kvinnligt kodat till att i större utsträckning utföras av män, vilket kan förstås utifrån mjölkens ekonomiskt allt större vikt för det enskilda lantbruket. Den ökade betydelsen gick hand i hand med en professionalisering, som innebar att hanteringen av mjölken förändrades. Mjölkmaskiner tillkom samtidigt som en stor del av arbetet med att förädla mjölken överfördes till mejerierna. ${ }^{510}$ Enligt intervjumaterialet kunde såväl bröder som systrar ansvara för mjölkningen. Till viss del tycks det ha funnits ett samband med syskonhushållets struktur. Fanns det flera systrar i hushållet var det regel att någon eller några av dem hade huvudansvaret för mjölkningen. På en gård med tre systrar och en bror hade två av systrarna ansvaret för mjölkningen. Brodern bistod med att få in djuren i ladugården och mocka, men mjölkade inte själv. Däremot deltog han i byns gemensamma körning av mjölk till mejeriet. ${ }^{511}$ Eftersom det vanliga var att det bara fanns en syster i hushållen var det dock, åtminstone på enheter med maskinell mjölkning, främst män som hade hand om mjölkningen. Det fanns dock små enheter med en bror och syster där den senare hade hand om mjölkningen. En kvinnlig informant som hade drivit ett jordbruk med två bröder berättade att hon handmjölkade ännu in på 1990-talet. Hon skötte även hushållssysslorna och arbetade ute. Mjölkningen såg hon närmast som en paus i slitet: "Det var en lättnad när man hade gått ute på åkrarna och jobbat och få komma hem och sätta sig på en pall hos korna och mjölka, det gick ju av sig självt - man vilade!"512 I några fall delades mjölkningsansvaret mellan en bror och syster, vilket understryker mjölkningens varierande könskodning. Männens deltagande i mjölkningen sträckte sig emellertid inte till att handmjölka; de mjölkade med maskin eller bistod en handmjölkande syster.

På några gårdar fanns ett syskon som var sjukt i tbc eller hade skador i armar, rygg eller höfter. När sådant förekom fanns det nästan alltid tre eller flera syskon på gården, och det klenare syskonet fick en lite friare roll i arbetsfördelningen. Det kan ligga nära till hands att se detta som ett sätt att lösa ett omsorgsbehov inom familjen. Så kan det säkert ha varit på en del syskonjordbruk, men i de fall som framkom i intervjuerna var syskonens funktionsnedsättningar inte 


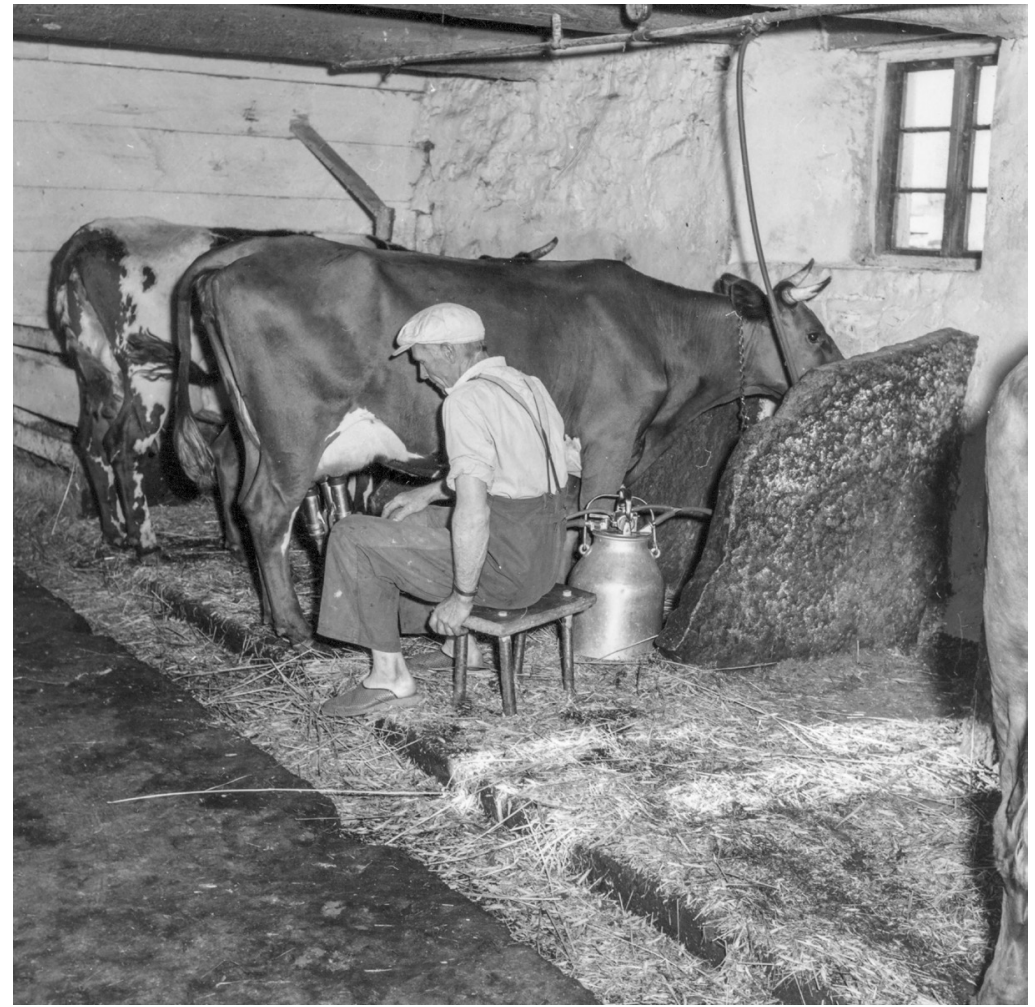

Med mjölkmaskinernas intåg förändrades traditionella roller i ladugården. Äldre man mjölkar. Öland, 1957. Foto: Kalmar läns museum.

så grava. Många gånger förefaller de ha utgjort en viktig arbetskraftsreserv. Fördelningen av arbetsuppgifter möjliggjorde en flexibilitet som innebar att de kunde utföra många mindre arbetsuppgifter eller skapa sig en egen sfär utifrån sina intressen - biodling, skrivarbete och hantverk för att nämna några exempel. I något enstaka fall fanns andra begränsningar. En bror ansågs exempelvis vara "trögtänkt" och hade lite svårt att hänga med, vilket gjorde att han inte sattes att göra svårare arbetsuppgifter eftersom "han aldrig skulle klara det". Han hade dock god hand med djur och jobbade mestadels i ladugården. ${ }^{513} \mathrm{Om}$ oförmåga eller skada drabbade en tilltänkt övertagare kunde större förskjutningar av arbetsfördelningen göras, som framgår av följande intervjureferat: 
Arne föddes på ett medelstort skånskt jordbruk och växte upp med sex systrar. Som ende son ansågs det självklart att han skulle överta. Fadern var emellertid hårdför och drev på sonen i arbetet, med följden att Arne lyfte för tungt och förstörde ryggen. Dessutom drabbades han av spanska sjukan och fick tillbringa tid på sanatorium. När fadern dog övertog Arne gården tillsammans med fyra av sina systrar. Till följd av sin skada deltog han dock inte fullt i utomhusarbetet och istället hade två av systrarna, tidvis med assistans av en dräng, hand om både arbetet på markerna och mjölkningen. ${ }^{514}$

Det förekom således att den vanliga könsarbetsdelningen modifierades, men i stort överensstämde fördelningen av arbetsuppgifter på syskonjordbruken med den bild tidigare forskning har gett av arbetsfördelningen på vanliga familjejordbruk. Bröder och systrar intog i praktiken samma roller som män och hustrur i arbetet. ${ }^{515}$ Två slutsatser kan dock dras. För det första uppgav flertalet informanter att arbetsfördelningen på syskonjordbruken var mycket rigid. Syskonen hade sina roller och diskuterade sällan fördelningen av de dagliga sysslorna. Varje syskon blev specialist på sitt och de bytte sällan arbetsuppgifter med varandra. En konsekvens av det var att jordbruket var sårbart om något av syskonen föll ifrån. Det finns visserligen inte så många sådana exempel i intervjumaterialet. De som finns visar att plötsliga bortfall vållade problem men att dessa kunde lösas inom ramen för syskongemenskapen. När den enda hemmavarande systern på en stor hälsingegård avled i 40-årsåldern fick de två återstående bröderna svårt att klara av vardagen. Krisen kunde dock lösas genom att en tidigare utflyttad syster som hade blivit änka flyttade hem igen och övertog sin systers arbetsuppgifter. ${ }^{516}$ Tillbakaflytten var frivillig och kom i ett skede då inget annat höll systern kvar. I andra fall var pliktkänslan större än lusten. När en av två bröder på ett mindre jordbruk i Västerbotten stod i begrepp att gifta sig och flytta ingrep fadern för att förmå en äldre ogift och utflyttad son att återvända, eftersom den kvarvarande brodern aldrig skulle klara gården ensam. Trots att den utflyttade brodern flyttat till södra Sverige och inte alls var inställd på att återvända flyttade han av moralisk plikt tillbaka och drev under åtskilliga år gården ihop med sin bror. ${ }^{517}$ 
För det andra är ett genomgående drag att ett av syskonen vanligen intog en mer ledande position. Någon skarp hierarkisk struktur var det inte fråga om; en informant beskrev det snarast som en arbetande förman. ${ }^{518} \mathrm{Ofta}$ sammanföll positionen med ett övergripande ansvar för gårdens ekonomi, och med något enstaka undantag innehades den av en av bröderna. ${ }^{519}$ I några fall var saken självklar på grund av att denne var ensam ägare till gården, men vanligare var att positionen inte grundades i ägande utan snarast verkar ha växt fram med tiden. Vem i syskonskaran som intog denna position tycks inte ha varit givet på förhand. På de nitton enheter där det fanns minst två bröder har i elva fall den äldste brodern tagit den driftsledande rollen. Åldern spelade således en viss, men inte avgörande, roll.

\section{Det svårfångade hushållet}

Att den driftsledande positionen ofta tillföll en man innebar inte att systrarna stod maktlösa. Med utgångspunkt i en diskussion om maktpositioner och ansvarsområden på 1900-talets familjejordbruk diskuterar Iréne Flygare uppdelningen av mäns och kvinnors arbete i två sfärer. Mot den manlige driftsledaren svarade då en kvinnlig position som ledande över framför allt hushållet. ${ }^{520}$ En sådan uppdelning stämmer väl in på syskonjordbruken i intervjuerna. På 24 av de 31 enheterna hade en syster huvudansvar för hushållet. Vad denna position innebar och hur den förhöll sig till driftsledaren och övriga syskon är dock inte helt tydligt. Å ena sidan finns flera exempel på systrar som hade en relativt stark ställning i kraft av att de var ytterst ansvariga för hushållet, men också i kraft av att de var delägare i gården. Deras ställning kan sägas ha motsvarat en mäktig matmor i ett vanligt familjejordbruk. Å andra sidan var det ungefär lika vanligt att systerns ställning i intervjuerna jämställdes med en hushållerska. Särskilt tydligt var detta när det gällde enheter med flera bröder. "Hon fick piglönen", som en informant beskrev det. ${ }^{521}$ I ett annat fall sades att en syster "var mer eller mindre piga hos sina bröder", trots att hon var delägare i gården. Trots att mangårdsbyggnaden var stor bodde hon i en kammare 
innanför köket som saknade garderob och fick förvara sina kläder i rummets kassaskåp. ${ }^{522}$

På de sju enheter där det inte bodde någon syster tillämpades andra lösningar. Enbart i två fall delade bröderna på ansvaret för hushållsarbetet. ${ }^{523}$ I tre var en av bröderna gift och hans maka intog den hushållsledande positionen. ${ }^{524}$ I en familj med två söner och två döttrar, födda mellan 1913 och 1922, gifte sig båda döttrarna under 1940-talet och flyttade från gården. Bröderna var då några år över trettio och i systrarnas ställe anställdes under några år en hushållerska. Efter hand tog bröderna hand om en del hushållssysslor, men de utflyttade systrarna kom regelbundet hem på helgerna för att hjälpa till. ${ }^{525}$ Att systrar på detta sätt kunde fortsätta ge stöd åt kvarboende syskon framgår ännu tydligare i det sjunde fallet.

Hilmas mor Klara var näst äldst i en syskonskara på fem barn på en mindre gård i Småland. Förutom barnen bestod hushållet av föräldrarna, två fastrar och barnens farfar. På mindre än ett år gick dock farfadern, en faster samt modern i familjen bort, händelser som dessutom lämnade den kvarvarande fastern sjuklig. På grund härav fick syskonen - då mellan två och sexton år - ta ett mycket stort ansvar för arbetet på gården. Efter att den äldsta systern flyttat för att börja studera till lärare fick Klara som femtonåring överta huvudansvaret för hushållet, men också för uppfostringen av sina yngre syskon. Hon träffade så småningom en man och förlovade sig, men kände att hon inte kunde lämna sina småbröder innan de vuxit upp. Äktenskapet fick därför anstå i flera år, och även efter giftermål och flytt till makens gård en halvmil bort behöll hon ansvaret för föräldragårdens hushåll. Hilma minns sin barndom som "ett enda cyklande fram och tillbaka" och konstaterar att modern höll igång båda hushållen. När Klaras make efter några år avled övergick gårdsdriften på en arrendatorfamilj, som flyttade in i mangårdsbyggnaden samtidigt som ett rum undantogs till Klara och Hilma. Även om de formellt bodde där flyttade de i praktiken tillbaka till föräldrahemmet där hennes två yngre bröder fortsatte driva gården. Cykelturerna mellan de två hemmen fortsatte dock under åtskilliga år. ${ }^{526}$

Det är lätt att se att ett antal avgörande händelser i detta fall formade förutsättningar för ett slags gränsöverskridande hushållsstruktur. 
Att ha ansvar för två hushåll innebar en mycket stor arbetsbörda. Berättelsen visar ändå på ett försök att kombinera ansvar och pliktkänsla gentemot yngre syskon och hemgården med ett eget liv med äktenskap, gård och familj. Huruvida det hade varit möjligt att upprätthålla denna struktur i längden är oklart, men att den alls förekom visar att även en ensam syster som i flera år var kvar på ett syskonjordbruk i vissa avseenden kunde bryta upp från det. Samtidigt är det möjligt att tolka berättelsen som att Klara egentligen aldrig lämnade gården, och att hon sedermera flyttade tillbaka styrker den tolkningen.

I detta och ett par liknande exempel framskymtar en flytande hushållsstruktur. Särskilt systrar hade en position där de till viss del inkluderades, eller lät sig innefattas, i syskonhushållet samtidigt som de inte var en permanent del av det. Följande två intervjureferat visar liknande handlingssätt.

I en syskonskara på två systrar och två bröder var Ingrid den enda som gifte sig och lämnade gården. När hennes make dog efter bara några års äktenskap blev hon ensam med två små barn. Samtidigt avled oväntat hennes mor, som till dess haft hand om gårdens hushåll. Ingrids bröder byggde då en villa till henne i direkt anslutning till föräldrahemmet, som de ungefär samtidigt köpte av fadern. När Ingrid och de två barnen flyttade in där blev de del i två hushåll sitt eget i lilla huset och syskonens på gården. Frukost och kvällsmat åt de för sig, men dagens övriga mål intogs gemensamt i stora huset. Ingrid hjälpte sin syster med gårdens hushåll och arbetade också utomhus och i ladugården tillsammans med bröderna. De två barnen fick mycket tidigt ta del i arbetet på gården. När systern senare blev sjuk och fick svårt att röra sig tog Ingrid över ansvaret för gårdens hushåll, men hon och hennes två barn fortsatte bo i det mindre huset. ${ }^{527}$

Eivors mor Anna var yngst i en skara på åtta barn, varav bara ett flyttade från bygden. Två systrar gifte och bosatte sig på torpställen något hundratal meter från gården. Senare gifte sig också Anna, dock utan att omedelbart lämna huset. I flera år bodde hon tillsammans 
med sin familj i ett kök med sovalkov på gårdens övervåning, innan de byggde eget hus ett stenkast bort. Även efter flytten var sammanhållningen stor mellan gårdens hushåll, där fyra ogifta syskon bodde kvar, och de tre utflyttade systrarna med familjer. Alla arbetade på olika sätt med arbetsuppgifter på gården, som också ägdes gemensamt av alla syskonen. Eivor beskriver barndomen som "ett slags storfamilj med alla inom tultavstånd". För barnen hade de små avstånden stora fördelar: bjöds det exempelvis ingen god mat hemma kunde de kila över och se vad som serverades i grannhuset. ${ }^{528}$

På dessa två gårdar flyttade syskon formellt ut från hushållet, men de befann sig i dess omedelbara närhet. De blev i praktiken ett slags kompletterande satellithushåll och arbetskraftsreserv. På ett allmänt plan visar exemplen hur syskon som flyttade och bildade familj fortsatte utföra viktiga arbetsinsatser på gården. Om förutsättningarna på gården förändrades genom dödsfall eller sjukdom kunde vakansen fyllas av ett återvändande syskon. Med utgångspunkt i förhållanden på irländsk landsbygd under 1900-talets första hälft kritiserar sociologen Jane Gray den traditionella synen på hushållen som separata ekonomiska enheter och visar att besläktade hushåll kunde ha ett nära samarbete. Särskilt framhåller hon att många hushåll utan familjebildning därigenom integrerades i ett flexibelt utbytessystem: "kinship networks comprised family and non-family households that exchanged support and worked to maintain and enhance the status of the extended family within the community". ${ }^{529}$

Betraktade på detta sätt kan de enskilda syskonhushållen ses som komponenter i ett sammansatt och dynamiskt hushållssystem, som sträckte sig bortanför den egentliga gården.

\section{Kärlek, syskon och föräldrar - tre relationer}

Hitintills har tyngdpunkten legat på hushållet som organisatorisk enhet, men det bestod i sin tur av flera individer och genomkorsades av sociala relationer. Ett intervjureferat tydliggör att dessa relationer är av central betydelse för att förstå hushållet. 
Klas mamma Vera kom från en medelstor gård i Bohuslän, där det totalt fanns fem syskon - Astrid, Vera, Beata, Helmer och Edit. Modern avled när de yngsta barnen bara var några år, vilket innebar att äldsta systern Astrid i stor utsträckning övertog hennes arbetsuppgifter. Fadern förestod dock ännu under många år jordbruket och bodde kvar på gården till sin död i början av 1930-talet. Vera gifte sig 1922 med en jordbrukare, arrenderade en gård några mil bort och fick två barn, Klas och Nils. På föräldragården fanns de fyra syskonen ogifta kvar, och förhållandena bestod även efter faderns bortgång. Det saknades emellertid inte förbindelser och äktenskapsplaner. Helmer, som var ende sonen och hade en lite starkare ställning, inledde ett förhållande med en kvinna som arbetade som mejerska i närheten. Omständigheterna, med tre ogifta systrar i hushållet hemma, var dock inte de bästa och inför de osäkra framtidsutsikterna rann förhållandet ut i sanden.

Systrarna saknade dock inte uppvaktare. Astrid hade under en lång följd av år ett förhållande med en man som var bosatt många mil bort. Mannen kom med jämna mellanrum till gården och kunde stanna en vecka, ibland längre. Under vistelserna på gården bodde han tillsammans med Astrid i ett eget rum, dit inget av de övriga syskonen då gick in. Det fanns uttalade äktenskapsplaner mellan de två, men de realiserades aldrig. När förbindelsen avslutades var Astrid nära 60 år. I sista brevet från mannen konstaterade han att de nog skulle ha blivit lyckliga tillsammans "om vi gift oss i yngre år", men att han "vet så väl hur bunden du varit med hemmet och kan inte vara bitter över att du inte kunnat komma till mig".

Även den yngsta systern Edit hade friare, och här tog saken en annan vändning. Några år efter att Astrids kärleksrelation upphörde gifte sig Edit, 45 år gammal, och flyttade från gården. Det sådde split mellan syskonen, särskilt mellan Edit och Astrid, som ansåg att hon svek gården och sina syskon. Enligt Klas resulterade schismen i ett livslångt dåligt samvete hos Edit. När hon och maken senare bosatte sig en bit från föräldragården gick Edit varje dag tillbaka "hem" för att hjälpa till med matlagning och hushållsarbete. ${ }^{530}$ 


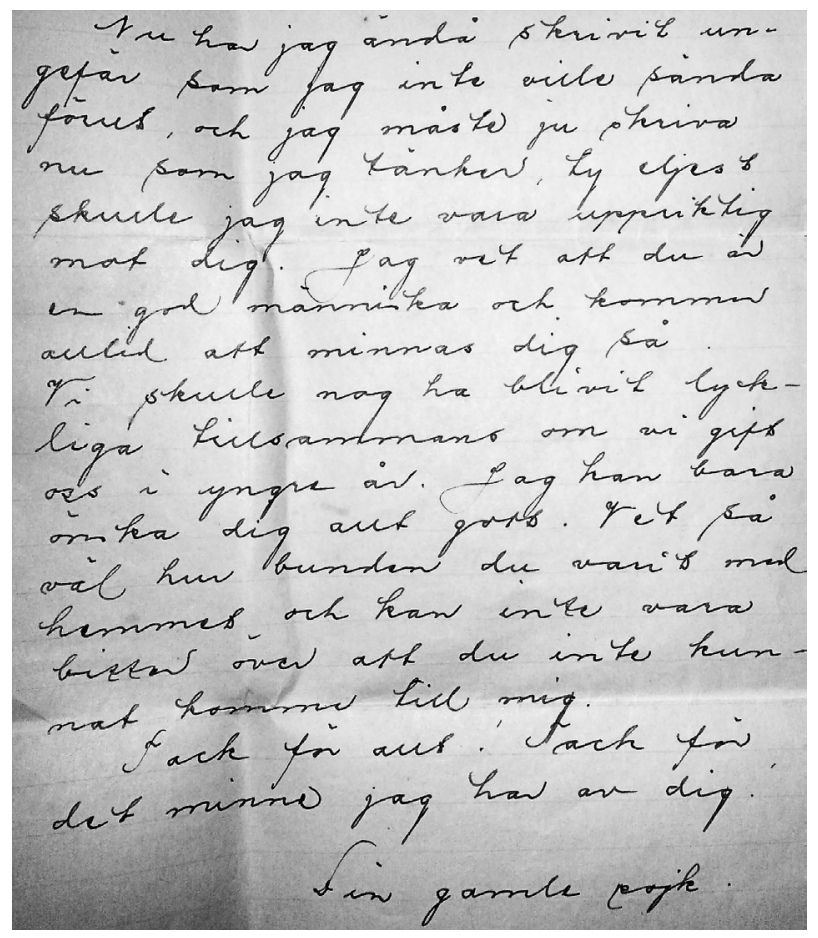

Utdrag ur det brev som Astrids tidigare tilltänkte man sände henne som avsked. Foto: författaren.

Det ligger nära till hands att förklara osämjan mellan systrar med deras olika livsval. För den äldre systern var bandet till gården och ansvaret över hushållet av ett sådant slag att hennes äktenskapsplaner slutligen gick om intet. Astrids bittra reaktion på Edits giftermål bör ses i ljuset av detta, men antyder samtidigt att hennes eget uppbrott inte varit ett enkelt val. Syskonens kärleksrelationer står i centrum för berättelsen och visar också på olika utfall. Edit gifte sig och flyttade ut, Astrid och Helmer bodde kvar på gården livet ut, men till priset av att förbli ogifta.

Frågan om äktenskap och möjligheterna att förena ett förhållande med den grundläggande syskongemenskapen är ett centralt spänningsfält i intervjumaterialet, men därutöver behövde i de flesta fall ytterligare två känsliga relationer hanteras. Den ena - relationen mellan syskonen och deras föräldrar - har berörts även i tidigare kapitel, 
men då har frågan mest gällt deras närvaro på syskonjordbruken ett visst år. Intervjuerna gör det möjligt att följa jordbruken över tid och då framträder föräldrar på betydligt fler enheter. Intervjuerna möjliggör också en djupare diskussion om vilken roll föräldrarna spelade för uppkomsten av syskonhushållen. Den andra känsliga relationen gäller förhållandet mellan syskon, dels mellan samboende, dels med eventuella utflyttade syskon. Det är ofrånkomligt att sådana relationer alltid är individuella, men när en grupp syskon lämnat hemmet och andra blivit kvar skapades två falanger inom syskonskaran beroende på livsval. Syskonens interna relationer rymmer således ofta både individuella och kollektiva aspekter.

\section{Äktenskap med förhinder}

Bland de 31 syskonjordbruken fanns fem där ett av de kvarboende syskonen hade gift sig, en klart mindre andel än i analysen av de tio socknarna i föregående kapitel, där nära 40 procent av syskonhushållen innehöll ett gift syskon. I de syskonskaror som intervjuerna kretsat kring fanns gott om exempel på syskon som gift sig, men de lämnade då det gemensamma hemmet. Ibland kunde sådana äktenskap - likt Edits i berättelsen ovan - dröja länge, så att flytten skedde först när syskonet med god marginal passerat 40 år. ${ }^{531}$

Gemensamt för de flesta syskonjordbrukarna i intervjumaterialet är således att de förblivit ogifta. I en hel del fall tycks parförhållanden, möjligen med undantag för någon kortvarig kärlekshistoria $\mathrm{i}$ ungdomsåren, helt ha saknats. Att informanterna inte har känt till några förbindelser behöver dock inte betyda att de inte förekom. Det är knappast ovanligt att kärleksförbindelser - då som nu - åtminstone till en början är hemliga, och det är inte säkert att uppgifter om dem traderats vidare eller över huvud taget talats om inom familjen.

De informanter som själva varit syskonjordbrukare kommenterade i några enstaka fall frånvaron av äktenskapsbildning. ${ }^{532}$ En manlig informant som drivit ett småbruk tillsammans med en bror menade att en anledning var barndomens upplevelser. Uppväxten på ett litet småbruk med många barn hade präglats av mycket knappa omständigheter, och det menade han bidrog 
till att särskilt de yngre syskonen senare i livet inte eftersträvat egna familjer. ${ }^{533}$ Men också arbetsförhållandena bör vägas in. En kvinnlig informant som haft ett jordbruk ihop med två bröder pekade på arbetsvillkoren som en viktig anledning till att det aldrig blev några allvarliga kärleksförbindelser. Med arbete från tidig morgon till sen kväll sju dagar i veckan var möjligheterna till sociala kontakter begränsade, särskilt i mer ensligt belägna områden. ${ }^{534}$ En annan faktor var sannolikt arbetets organisation. När arbetskraften i allt större utsträckning inskränktes till den egna familjen innebar det att sociala kontakter i form av inhyrd arbetskraft försvann, men också att arbetet upptog en allt större del av familjemedlemmarnas tid.

Det finns dock också exempel på att syskon hade kända förhållanden, och de ger viktig information om hur sambandet mellan syskonenheten och äktenskapsplanerna såg ut.

Katarinas farbror Abraham drev en gård tillsammans med två bröder och en syster. I hushållet ingick dessutom syskonens mor, som levde tills Abraham var närmare 50 år. Under många år var han förlovad med Frida, som i sin tur drev en närliggande gård tillsammans med sin bror och svägerska. Inom Fridas familj fanns en förhoppning att Abraham och Frida skulle gifta sig och flytta ihop på hans gård, men planerna realiserades aldrig. Paret gjorde ibland söndagsutflykter tillsammans i hans bil och tillbringade semestrar ihop. Frida hade ett eget rum i övervåningen på sin gård och ibland gick Abraham upp till henne på lördagskvällarna och sov över till söndagen. ${ }^{535}$

Abraham och Frida hade en allmänt erkänd och långvarig relation, som dock aldrig utmynnade i ett regelrätt äktenskap. Vad som låg bakom det uteblivna giftermålet går inte att säga säkert, men Katarina menar att en avgörande faktor var hushållsstrukturen på hemgården. Förutom två ogifta bröder, som i huvudsak arbetade i jordbruket, basade Abrahams ogifta syster och mor över hushållet. Att ytterligare en kvinna skulle ta plats i hushållet - dessutom överordnad de kvinnliga släktingarna - måste, menar Katarina, ha tett sig mer eller mindre otänkbart: "Platsen var upptagen!" 
I en personlig skildring av livet på en gård i Närke under 1900-talets första hälft beskriver Ingrid Vistrand en liknande situation för sin moster och morbror. Förutom de två syskonen fanns en syster (Ingrids mor), som gifte sig och lämnade gården. När syskonens moder dog var yngsta dottern Herty 23 år och övertog i praktiken hennes plats. Vid arvskiftet efter faderns död ett drygt decennium senare antyddes att brodern, då snart 40 år, borde stadga sig och bilda familj.

Uttalandet drabbade Herty. Hon hade varit husmor i 12 år.

- Vad ska det bli av mig? Vart ska jag ta vägen i så fall, sa hon.

Detta diskuterades aldrig mer i familjen. Ämnet var tabu. Herty blev delägare i gården och de fortsatte sin dagliga gärning, var och en med sitt. ${ }^{536}$

Sett till samtliga intervjuer är problemet hur en inflyttande maka skulle kunna samexistera med hemmavarande syskon den mest förekommande förklaringen till att syskonen förblev ogifta. Relationen hade ofta en könsmässig slagsida. Det är främst män som stått inför svårigheten att gifta sig och bo kvar, men det stora hindret förefaller ha bestått i att det ofta redan fanns en ogift kvinna hemma. Gjorde det inte det var saken enklare: bland de 31 syskonjordbruk fanns sex som enbart bestod av bröder, och på tre av dem gifte sig en av bröderna. Vägen till äktenskap var dock sällan enkel och fanns en syster med i bilden kunde det innebära öppna motsättningar.

Tillsammans med sina föräldrar och två yngre syskon flyttade Vilhelm på 1920-talet till en gård i Blekinge. Tre äldre systrar hade redan lämnat boet, men Vilhelm, hans bror och hans syster förblev hemma år efter år. Så småningom träffade Vilhelm Hulda, men deras relation hölls hemlig med hänsyn till hans familjeförhållanden. För att de skulle vara närmare varandra fick hon anställning som piga på gården. När förhållandet dem emellan blev känt träffade det systern, som i vredesmod lämnade gården. Vilhelm och Hulda gifte sig senare och bildade familj, men hans bror bodde kvar på gården. Relationen mellan Hulda och hennes svägerska förblev infekterad livet ut. ${ }^{537}$ 
Att förhållandet hölls hemligt visar den sprängkraft som ett äktenskap kunde ha på ett syskonjordbruk. Hur relationen kom i dagen framgår inte av berättelsen, men systerns reaktion antyder att hon såg sin plats hotad. Istället för att vara kvar i hushållet och sannolikt bli underställd sin svägerska lämnade hon hemmet. Ett giftermål hotade emellertid inte på samma sätt broderns position, varför han stannade kvar i hushållet.

På de 25 enheterna med både systrar och bröder förekom enbart två äktenskap, och i båda fallen var det systrar som gifte sig. I ett av fallen flyttade paret ut till ett eget hus efter några år, men i det andra bodde en ogift bror kvar tillsammans med systern och hennes familj. ${ }^{538}$ Gifta systrar var således något mycket ovanligt på syskongårdarna och sågs sannolikt knappt som ett alternativ. Det innebär emellertid inte att de saknade kärleksrelationer eller hyste förhoppningar om äktenskap. Tvärtom - i intervjumaterialet förekommer fler uppgifter om systrars relationer än om bröders. Ofta fanns då andra hinder, som framgår av nedanstående exempel.

Pers faster Svea var äldsta barnet i en syskonskara på sex barn på en relativt välmående gotländsk gård. Tre av barnen gifte sig och lämnade gården, men Svea och två bröder blev efter faderns död kvar tillsammans med modern. Efter några år förälskade Svea sig i en provassistent som med jämna mellanrum besökte gården för att kontrollera mjölkkvaliteten, en kärlek som visade sig vara besvarad. Modern hade dock starka invändningar mot förbindelsen och gav tydliga direktiv om att Svea skulle förbli hemma, särskilt som ingen av de två hemmavarande bröderna tycktes ha utsikter att genom giftermål föra en annan kvinna till gården. Att mjölkkontrollanten skulle flytta in var helt otänkbart, särskilt som Svea inte var delägare i gården. Den uppvaktande mannen fick därför så att säga korgen av modern. Svea och hennes bröder förblev ogifta. ${ }^{539}$

För Abraham och Vilhelm var det svårigheten att finna en plats för en utomstående i hushållet som stod i vägen för äktenskap, men i ovanstående exempel var problemet närmast det omvända. 
Vid sidan av den åldrade modern var Svea den enda kvinnan på gården och i den egenskapen kunde hon inte undvaras. Det är dock värt att märka att en avgörande faktor enligt informanten var att ingen av bröderna tycktes ha några framtidsutsikter på äktenskapsfronten. Sambandet mellan äktenskap och hushållets sammansättning framträder närmast som ett pussel: en bror med en potentiell äktenskapspartner hade möjliggjort en rockad - syster ut, maka in - men nu måste systern bli kvar. I exemplet framträder den äldre generationens maktposition tydligt, även om det inte går att veta exakt på vilka sätt den manifesterades. Att det var modern som höll kvar dottern i en påtagligt patriarkal struktur kan framstå som motsägelsefullt men ligger väl i linje med tidigare forskning. I sina undersökningar av svenska familjejordbruk visar Iréne Flygare att kvinnor, särskilt mödrar, har spelat en avgörande roll för att upprätthålla den patrilinjära arvsföljden på gårdarna: döttrar har sällan lyfts fram som möjliga efterträdare eller fått ta del i mer ansvarsfulla moment $i$ arbetet. ${ }^{540}$

Att döttrarna måste vara kvar och sköta hushållssysslorna var ett skäl till att föräldrarna motsatte sig deras äktenskapsplaner, men det vanligaste skälet var snarare socialt. En kvinna som med sina två bröder bodde på föräldragården, som sönerna hade köpt av föräldrarna, hade flera uppvaktare men fadern vägrade godkänna förbindelserna då han inte ansåg någon av dem vara fin nog. ${ }^{541}$ I intervjuerna framkom nio fall då föräldrar uttryckligen opponerade sig mot sina döttrars giftermålsplaner på grund av att hennes utvalde inte motsvarade deras krav på status och besuttenhet. Utsikterna tycks ha varit extra dåliga om uppvaktaren inte var bonde och hade egen gård. Föräldrarnas vägran att acceptera en måg hade stor betydelse; ställda inför detta har giftermålsplanerna vanligen skrinlagts. I enstaka fall då döttrar framhärdade och drog saken till sin spets resulterade motsättningen i öppen konflikt. I en intervju nämndes ett fall då föräldrarna inte bara uteblev från vigseln utan också nekade det unga paret traditionell skjuts till kyrkan. En häst fick uppbringas hos grannar. Det dröjde mer än tio år innan schismen i viss mån upphörde..$^{52}$

Det finns ett par exempel på att söners trolovningar gick om intet 
på grund av föräldrarnas motstånd, men det tycks främst ha varit ett öde som drabbade kvinnor. Varför fann de sig i situationen? Någon laglig rätt att hindra äktenskap existerade inte längre. Den giftomannainstitution som i äldre tider tillförsäkrat män rätten att förvägra sina döttrar äktenskap hade upphävts 1872. Regeln slopades då för kvinnor som var myndiga, vilket de enligt 1882 års regler blev vid 21 års ålder. Den rättsliga förändringen tycks dock inte ha hindrat att institutionen i praktiken fortlevde och att föräldrars inflytande över döttrarnas val av äktenskapspartner var betydande. Hur föräldrarna utövade sin makt över döttrarnas äktenskapsplaner framgår sällan av intervjuerna. Sannolikt rörde det sig om en kombination av socialt tvång (en informant talade om skandalen att bli utslängd hemifrån) och ekonomiska förhållanden, men kulturella aspekter som dygden att lyda sina föräldrars vilja spelade säkert in.

\section{Föräldrarna och generationsväxlingen}

Alla de 31 syskonenheterna hade övertagits från föräldragenerationen, vilket förstärker slutsatsen att syskonjordbruk regelmässigt uppstod som resultat av ett generationsskifte. ${ }^{543} \mathrm{I}$ ett tiotal fall hade gården förvärvats av föräldrarna någon gång under 180o-talets senare hälft eller vid inledningen av 1900-talet. Vanligare var dock att fastigheten hade funnits i släkten i flera generationer, som längst ända sedan 1500 -talet. ${ }^{544}$ Att syskonjordbruken regelmässigt uppstod vid en generationsväxling ligger väl i linje med resultaten i de föregående kapitlen och riktar fokus mot syskonens föräldrar och deras betydelse för utvecklingen. Eftersom merparten generationsväxlingar på svensk landsbygd inte innebar att ett syskonjordbruk etablerades inställer sig frågan om föräldrarna på sådana enheter genom sitt agerande understödde att flera arvingar stannade på gården. Även om varje generationsskifte påverkades av en rad faktorer (egendomens storlek och struktur, föräldrarnas status och hälsa, arvingarnas antal och förutsättningar et cetera) och i en mening var unikt går det att med utgångspunkt i föräldrarnas roll på de 31 studerade enheterna urskilja tre varianter. 
I tre familjer framträder ett traditionellt enarvingeideal: det fanns från föräldrarnas sida en tydlig ambition att överlåta fastigheten odelad till en av sönerna. Överlåtelsen skedde genom att efterträdaren köpte fastigheten av föräldrarna och avsikten tycks inte ha varit att de övriga syskonen skulle stanna hos brodern. Ibland framgår att föräldrarna planerade för övriga barns framtid utanför gården.

Svens mor var näst äldst av sex syskon på ett mindre jordbruk i Blekinge. De fyra äldsta syskonen gifte sig och lämnade gården, som i mitten av 1950-talet såldes till den sist hemmavarande sonen. Samtidigt inköptes en mindre villafastighet i samma by till den enda hemmavarande dottern. Hon blev dock kvar på gården, eftersom föräldrarna behövde vård och hennes egen arbetskraft behövdes i jordbruket. Boendeförhållandena förblev intakta även sedan föräldrarna några år senare gått ur tiden och systern formellt tillskiftats villan. Ännu vid systerns död 2011 var den obebodda villan i hennes ägo. ${ }^{545}$

I detta fall är det uppenbart att föräldrarna planerade en framtid för dottern utanför gården, men att dessa planer aldrig realiserades. Att systern behöll villan i över 50 år kan tolkas som en säkerhetsåtgärd; skulle något inträffa som tvingade henne från gården fanns en reträttpost. I intervjun framhävdes två kvarhållande krafter föräldrarnas behov av omsorg och gårdens krav på skötsel - och till dem kan läggas ansvaret för hushållet. Tilläggas kan också att utlösta syskon trots föräldrarnas planer ibland inte hyste någon avgörande längtan till ett liv utanför gården. I enstaka fall kunde en sådan inställning påverka formerna för generationsskiftet. Två informanter, äldre syskon som drivit ett jordbruk tillsammans, menade att faderns vilja varit att sonen ensam skulle överta gården. Ställd inför detta kände sig emellertid dottern bortkörd från sitt hem, en reaktion som påverkade föräldrarna i sådan grad att de istället överlät gården på båda syskonen. ${ }^{546}$

När föräldrar på liknande sätt aktivt medverkade till att mer än ett syskon övertog gården är det enligt min mening rimligt att tolka generationsskiftet som en planerad flerarvingestrategi. I 
intervjuerna finns sex sådana exempel, och samtliga ledde till att två syskon övertog gården ihop. I fyra fall såldes gården till två söner, i de övriga två gavs den som gåva till en bror och en syster som saknade andra syskon. ${ }^{547}$ På två av de fyra gårdar som övertogs av två bröder ingick en syster i hushållet utan att vara delägare i gården. Eftersom föräldrarna i dessa fall själva överlät gården och därmed etablerade en struktur med flera hemmavarande syskon, är det rimligt att tolka utvecklingen som föräldrarnas intention.

Det finns enstaka exempel på att föräldrar aktivt styrde barnen mot en gemensam framtid på föräldragården utan att för den delen överföra ägandet under sin livstid.

I en familj med sju syskon på en relativt stor gård i Västergötland bestämde föräldrarna dels att inget av barnen skulle gifta sig, dels vilka sysslor de skulle ha. De två äldsta sönerna skulle ta över jordbruket, en klenare son med läshuvud fick läsa till präst och den fjärde sonen fick ta hand om trädgården och arbeta utanför hemmet. Två av systrarna skulle stanna hemma, ta hand om hushållet och hjälpa till i jordbruket. Den tredje systern flyttade med den bror som läste till präst för att sköta hans hushåll. Föräldrarnas vilja åtföljdes på alla punkter, även efter deras död. Trots att två syskon flyttat förblev gården efter föräldrarnas död i syskonens gemensamma ägo och ingen av dem gifte sig. Två av dem var trolovade i yngre år, men främst på grund av föräldrarnas starka vilja bröts förlovningarna. ${ }^{548}$

Sett till samtliga intervjuer är ovanstående det fall där föräldrarna förefallit ha varit mest styrande, inte bara vad gäller hur gården skulle skötas efter deras död utan även hur barnen skulle leva sina liv. Det visar att föräldrar kunde ha en ledande roll utan att för den skull överföra gården till barnen före sin död, och åtta av de 31 syskonjordbruken måste sägas ha uppstått med föräldrarnas aktiva medverkan.

Det stora flertalet syskonjordbruk i studien uppstod dock inte på grund av föräldrarnas aktiva inverkan utan snarare på grund av deras underlåtenhet att lösa successionsfrågan. På 20 av de 31 
enheterna inleddes överlåtelsen först när någon av föräldrarna dog. Hur hushållet vid det tillfället såg ut varierade och i flera fall kan generationsväxlingen redan sägas ha pågått ett par år, med följden att några syskon hade delat på gårdens sysslor medan andra flyttat ut. I andra fall, särskilt om föräldrarna avled i relativt ung ålder, bodde samtliga barn ännu hemma. Gemensamt för denna kategori är dock att föräldrarna inte hade vidtagit några större förberedelser för generationsskiftet och vid deras död blev därför alla barnen delägare i gården. I hälften av dessa fall vidtog ingen efterföljande inlösensprocess; alla arvingar blev genom bouppteckningen delägare i dödsboet och så kunde förhållandet förbli i åtskilliga år. Det fanns bland de ingående jordbruken dödsbon som bestod $\mathrm{i}$ 40 år innan arvskiftet genomfördes - ett arvskifte som inte sällan resulterade i att samtliga syskon fick lika delar i fastigheten. Med ett så utdraget förlopp hann flera syskon avlida under tiden, men eftersom de inte hade andra arvingar än dödsboets delägare kunde arrangemanget bestå. ${ }^{549}$

När inlösen genomfördes var regeln att de kvarboende syskonen köpte ut dem som flyttat. Handlingen var kollektiv: de kvarboende syskonen köpte gemensamt de övrigas arvslotter och bibehöll därmed sitt jämbördiga ägandeförhållande. I något enstaka exempel kunde också ett av de hemmavarande syskonen sälja sin arvslott till de övriga. I ett hushåll med fem hemmavarande syskon löste tre av dem ut de övriga två, som dock bodde kvar på gården. ${ }^{550} \mathrm{I}$ intervjuerna framkom endast ett exempel på en successiv inlösen: de fem syskonen på en bohuslänsk gård som jag tog upp i samband med att jag diskuterade syskonens relationer ovan. I arvskiftet efter modern delades gården efter gällande praxis mellan fadern och barnen. Vid faderns död många år senare beslöt syskonen att hans andel skulle tillskiftas sonen Helmer, som därefter genom separata transaktioner med sina fyra systrar löste in deras andelar. Något omedelbart övertagande var det dock inte fråga om; inlösen av systrarnas arvslotter inleddes på 1940-talet men omfattade åtskilliga jordtransaktioner och avslutades först i mitten av 1970-talet, då Helmer var över 70 år gammal. ${ }^{551}$

Det vanligaste var således att syskonjordbruk uppstod på grund 
av att inlösen inte genomfördes fullt ut. Samtidigt finns inget likhetstecken mellan en arvfallen jordbruksfastighet och ett syskonjordbruk; de allra flesta arvfallna gårdar övertogs inte gemensamt av syskon. Varför löste inte bara ett av syskonen ut de övriga på syskongårdarna? I tidigare forskning har höga lösensummor nämnts som en möjlig orsak till att flera syskon blev kvar på föräldragården. ${ }^{552}$ Jordpriserna ökade under slutet av 1800-talet och fick ordentlig fart under 1900 -talet. Mellan 1900 och 1950 fyrdubblades jordbruksfastigheters taxeringsvärden, samtidigt som jämförbara index enbart ökade 2,5 gånger. ${ }^{553}$ Att höga priser försvårade inlösen vid generationsväxlingar uppmärksammades också i samtiden. ${ }^{554}$

En informant menade att svårigheter att lösa ut varandra var en bidragande orsak till att syskonen bodde kvar. På den aktuella fastigheten fanns flera lån upptagna och trots att flera syskon flyttade förblev egendomen i gemensam ägo. ${ }^{55}$ De höga jordvärdena gällde dock inte enbart syskonjordbruk och på de flesta gårdar genomfördes trots allt inlösen så att en arvinge övertog hela fastigheten. På flera av de undersökta syskongårdarna tycks inte heller ekonomin ha varit särskilt skral, flera informanter har påtalat att ekonomin varit påfallande god och att syskonen var helt obelånade. ${ }^{556}$ Att det i vissa fall förekom partiell inlösen, där framför allt utflyttade syskon löstes ut, indikerar också att höga lösensummor inte förmår förklara samägandet.

Det fanns inte heller någon entydig korrelation mellan boendemönster och ägande. Vissa syskon fortsatte att bo ihop utan att samäga, andra flyttade men behöll sin andel i gården. En mer rimlig utgångspunkt är att samägande mellan arvingar bestod därför att det innebar både säkerhet, delaktighet och status för de enskilda delägarna. Iréne Flygare och Maths Isacson betecknar jordägandet som "en av det moderna samhällets mer sega strukturer, fortfarande förknippat med status, förpliktelser och makt" och konstaterar att den som ägt jord "inte i förstone varit villig att släppa den ifrån sig." ${ }^{557}$ Resonemanget avser jordbruksstrukturen på ett övergripande plan, men kan appliceras på det enskilda syskonjordbruket. Att samägandet i de flesta fall inte uppkom förrän i och med föräldrarnas död medför att arvingarna inte längre var 
några ungdomar. Hade de vid det laget inte lämnat gården är det knappast sannolikt att delägarskapet gjorde dem mer benägna att flytta därifrån. Det omvända är mer sannolikt - att äga en andel i gården minskade risken för att man skulle behöva lämna den.

Generationsväxlingen kunde med andra ord genomföras på mycket olika sätt och föräldrarnas agerande var av stor betydelse. Syskonjordbruk kunde etableras även om föräldrarna hade överlåtit gården på en av sönerna, men oftare förefaller det ha varit deras underlåtenhet att planera generationsskiftet som påverkade utgången: det gjorde hemmavarande arvingar till delägare i fastigheten, vilket gav dem starka incitament för att behålla strukturen. Varför lät då föräldrar bli att överlåta gården i förtid? Ett svar ligger sannolikt $i$ att föräldrarnas betydelse inte enbart kan ses i förhållande till generationsväxlingen.

\section{Betydelsen av föräldrars närvaro och frånvaro}

Oavsett om föräldrarna aktivt verkade för att gården skulle övertas gemensamt eller avstod från att bestämma hur arvskiftet skulle verkställas, var deras närvaro tydlig. På många syskonjordbruk blev de kvar i hushållet till döddagar. Eftersom det var vanligt att åtminstone en av dem fick uppleva sin 80- eller rentav 90-årsdag innebar det att generationernas samboende blev en lång historia. På mer än hälften av gårdarna fanns minst en förälder kvar tills yngsta barnet fyllt 40 år, vilket innebar att de äldre barnen hann bli 50 eller i enstaka fall 60 år innan flergenerationshushållet upphörde. I en handfull fall fanns dessutom ytterligare någon äldre släkting i hushållet, vanligen någon av syskonens fastrar eller mostrar. ${ }^{558}$ Syskonjordbruken var med andra ord inte bara horisontellt utvidgade med flera släktingar i samma generation, i normalfallet fanns även en vertikal utvidgning genom att någon i föräldragenerationen fanns kvar.

Inte i något enda fall drog föräldrarna sig tillbaka och avskilde sig från barnen genom att bilda ett fristående hushåll i ett eget hus eller en separat del av mangårdsbyggnaden. ${ }^{559}$ Som framgick av enkätmaterialet i kapitel 3 var sådana undantagsboenden ännu 
relativt vanliga på landsbygden under 1900-talets första hälft. Utifrån egna intervjuer och folkminnen har Iréne Flygare visat att på familjejordbruk som överfördes inom släkten utgjorde de gamla i regel ett eget matlag skilt från gårdens yngre brukarfamilj, åtminstone så länge de var någorlunda friska. När en av dem gick bort var det dock vanligt att den som blev kvar uppgick i det andra hushållet. ${ }^{560}$ Att detta mönster inte återfanns på syskonjordbruken förklaras sannolikt av att merparten av dem inte överläts under båda föräldrarnas levnad, varför den ursprungliga hushållsgemenskapen egentligen aldrig upphörde.

Eftersom föräldrarna förblev i hemmet livet ut ordnades omsorgen på äldre dagar inom hushållets ram. I intervjuerna framkom ett enda exempel på att en äldre släkting inte vårdades livet ut $\mathrm{i}$ hemmet. ${ }^{561}$ Behovet av stöd och omvårdnad varierade, från föräldrar som in i det sista skötte sig själva till dem som var sängliggande i åratal och kontinuerligt måste passas.

Att föräldrarna var kvar i hushållet indikerar en stark familjesammanhållning men riktar också fokus mot moraliskt färgade drivkrafter. Föräldrarnas närvaro väckte säkerligen hos många arvingar en pliktkänsla - mot gården, föräldrarna och familjen som gjorde det svårare att bryta upp. Däremot tycks denna pliktkänsla inte ha varit religiöst grundad. Det fanns starkt kyrkliga syskonhushåll, men intervjuerna ger inte bilden av att religiositet i allmänhet var ett utmärkande drag för dem.

På tre av syskonjordbruken fanns ingen i föräldragenerationen kvar när det etablerades. I två fall hade modern avlidit varpå fadern flyttat från hemmet när han gifte om sig och emigrerade sedan till Amerika. ${ }^{562}$ I det tredje fallet lämnade föräldrarna byn i samband med att två av sönerna övertog gården. ${ }^{563}$

De sistnämnda exemplen pekar på att också frånvaron av föräldrar spelade en viss roll. I de två familjer där modern avlidit och fadern lämnat gården tog syskonen över gårdsbruket när de var i tjugoårsåldern. Informanterna menade att detta svetsade samman syskonen som grupp. Liknande familjetragedier förekom dock i fler exempel. I elva av familjerna drabbades en förälder av sjukdom eller dog innan barnen uppnått myndig ålder. I ett par familjer 
föregicks dessa dödsfall av flera års sjukdom då föräldern mestadels var sängliggande. ${ }^{564}$ Omständigheterna innebar att barnen tidigt fick överta de vuxnas arbetsuppgifter och för att klara vardagen krävdes en kraftsamling, där alla familjemedlemmar måste bidra i största möjliga mån. Krisen uppstod oavsett vilken förälder som drabbades, däremot anpassade sig hushållet på olika sätt för att kompensera för arbetskraftsbortfallet, i jordbruket såväl som i hushållet. I vissa fall blev dock effekterna annorlunda när modern avled, särskilt om det fanns yngre barn i hemmet. I en familj var de två yngsta barnen bara två och sex år när modern gick bort. En äldre syster fick då inte bara överta hushållssysslorna, utan även huvudansvaret för småsyskonens uppfostran. Hon blev, knappt femton år gammal, familjens nav. ${ }^{565}$

Med tanke på förutsättningarna är det inte konstigt att banden mellan syskonen växte sig särskilt starka i dessa familjer, särskilt om åldersskillnaderna var stora. Leonore Davidoff har pekat på betydelsen av familjer med stora barnaskaror i England i slutet av 180o-talet, sedan barnadödligheten gått ner men innan födelsetalen sjönk. När barnen föddes under en lång tidsperiod skapade åldersspannet mellan det äldsta och yngsta syskonet en särskild dynamik mellan syskonen: "the elder acted as caretakers, educators, and playmates of the younger members of the family". ${ }^{566}$ Davidoffs poäng är att visa på den stora förändring som inträffade när den viktorianska storfamiljen vid ingången till 1900-talet ersattes av radikalt mindre barnaskaror med små åldersskillnader, och hon pekar särskilt på hur äldre systrar tidigare kunde överta moderns uppgifter eller rollen som den stereotypa ogifta fastern. ${ }^{567}$ Ett liknande mönster kan skönjas på åtminstone sex av gårdarna i intervjumaterialet, där en äldre syster blev en sorts reservmor för sina yngre syskon. Någon motsvarighet där en son agerade reservfar tycks inte ha funnits. 


\section{Eget rum eller delat?}

Syskonens gemensamma vardag på gården innebar att de levde nära varandra, men hur nära? En indikation på hur gränsen mellan gemensamt och privat gestaltat sig kan vara hur bostadens utrymme delades. Att syskon delar sovrum under uppväxten är naturligt, men hade de eget rum som vuxna? I äldre tid var en sådan privat sfär knappast en möjlighet för någon på gården på grund av hushållets storlek med barn och tjänstefolk. ${ }^{568}$ På syskonjordbruken saknades dock vanligen både barn och tjänstefolk. De 31 gårdarna hade mellan två och tolv rum förutom kök och hall, vilket gav väldigt olika förutsättningar, och boendeformerna uppvisade stora variationer. Ett tydligt mönster är dock att det inte var ett självändamål att varje syskon skulle ha ett eget rum, ens när det var praktiskt möjligt. I mer än varannan familj delade två eller fler syskon sovrum i vuxen ålder och inte sällan livet ut. En viktig skiljelinje går mellan jordbruk med två syskon och de med tre eller fler. Av de förra var det bara tre där syskonen delade sovrum, av de senare tvärtom bara tre (samtliga med tre syskon) där de inte delade. Att sannolikheten för delade sovrum ökade med antalet syskon är knappast förvånande. Det var mycket sällsynt att alla rum i bostaden värmdes upp året runt, och en relativt stor del av boytan upptogs ofta av ett större rum, salen, som främst användes vid större högtider. ${ }^{569}$ Vilka syskon som delade rum och vilka som fick eget kan ändå kasta visst ljus över syskonens inbördes relationer.

Den viktigaste fördelningsprincipen var kön. Att en bror och en syster delade rum var sällsynt och i hela materialet förekommer enbart två sådana exempel. ${ }^{570}$ Två eller tre bröder kunde bo tillsammans i "pojkarnas rum" - som också kunde fungera som ett andra, mer slutet vardags- eller umgängesrum - eller dela upp sig på flera rum. ${ }^{571}$ Ibland markerade en sådan uppdelning brödernas inbördes relation, så att den driftsledande brodern hade eget rum, men det förekom också att en klenare eller sjuklig bror fick bo för sig själv. ${ }^{572}$ Däremot förefaller inte placeringen i syskonskaran haft någon större betydelse för vilka som delade rum och vem som hade eget. En mer avgörande faktor var om den äldre generationen ännu var i livet. En förälder kunde bo i egen kammare, men det var 
ungefär lika vanligt att denna delades med ett barn - för moderns del en dotter, för faderns en son. ${ }^{573} \mathrm{I}$ ett hushåll med fyra systrar och en bror samt deras mor delade en mellansyster rum med modern. De övriga tre systrarna delade rum och brodern hade eget. ${ }^{574} \mathrm{I}$ de flesta fall fanns enbart en syster på gården och hon sov vanligen $\mathrm{i}$ ett rum nära köket, som ibland också fungerade som vardagsrum på dagtid. ${ }^{575}$

Rumsfördelningen syskonen emellan var mycket beständig och förändrades egentligen bara vid dödsfall eller allvarlig sjukdom. Astma, svårigheter att gå i trappor och liknande kunde tvinga fram förändringar, och om en hädangången förälder hade haft egen kammare övertogs den av något syskon. Boendemönstret var så invant att det bestod också i den handfull fall då syskonen gemensamt flyttade från gården. Två bröder som hade delat rum i alla år fortsatte göra det även sedan de flyttat till ett serviceboende. Till och med möbleringen behölls: sängarna i var sitt hörn och ett bord för kortspel mitt i rummet. ${ }^{576}$ Två systrar som sedan barnsben sovit bredvid varandra i en utdragbar bäddsoffa fortsatte med det även sedan de flyttat till lägenhet och fått hemtjänst. I detta fall fanns ett slags samhörighet till och med inför döden. Endast tre dagar efter den ena systerns bortgång drabbades den andra av en hjärtinfarkt. Begravningarna hölls med bara någon veckas mellanrum. ${ }^{577}$

Syskonens rumsdelande ska inte överdrivas - de flesta hade trots allt eget sovrum - men inte heller underskattas. Här framträder ett mönster som antyder att det ibland saknades en strävan hos syskonen att skapa en egen privat sfär. Vid sidan om boendemönstret finns ytterligare ett område som synliggör gränsen mellan privat och gemensamt: hur pengar fördelades och användes.

\section{Gårdsekonomi och hushållskassa}

I vilken utsträckning levde syskonen i ekonomisk gemenskap? I ungefär var tredje intervju gick det inte att få säkra besked om hur syskonens ekonomiska relationer såg ut, och nedanstående resonemang är därför behäftat med viss osäkerhet. Baserat på de fall där uppgifter kunde ges framträder dock konturerna av en gemensam 
ekonomi. Grunden för ekonomin var gården och de intäkter den genererade. Mjölken var den stora intäktskällan, men också ägg, grönsaker och spannmål kunde inbringa pengar. Eftersom de studerade jordbruken hade en hög grad av självförsörjning var det dock inte alltid fråga om så stora summor. Om ett syskon delvis lönearbetade utanför gården kunde det ge ett viktigt inflöde av reda pengar. Det är därför intressant att notera att sådana förtjänster i princip alltid lades in i den gemensamma hushållskassan.

Det fanns undantag från den ekonomiska samhörigheten, och den viktigaste faktorn förefaller ha varit ägandeförhållandena på gården. På de tre enheter där hela gården ägdes av ett syskon saknades gemensam ekonomi och om bara några hemmavarande syskon innehade gården fanns en skiljelinje gentemot de övriga, vilka i alla fall utom ett var systrar. ${ }^{578}$ De sistnämndas position kunde vara svår på flera plan. Dels kunde det stundom vara oklart vilka medel systern kunde använda för inköp till hushållet, vilket i ett fall medförde att hon bekostade inköpen med sina egna pengar och inte gårdens. ${ }^{579}$ Dels var positionen ekonomiskt ofördelaktig i ett längre perspektiv. Dessa kvinnor gjorde stora insatser för gården och hushållet, men till följd av att de varken ägde egendom eller var anställda fick de ingen del i fastighetens värdestegring och kvalificerade sig enbart för den lägsta pensionsnivån. I ett par fall blev syskonen uppmärksammade på dessa risker av utomstående och kunde konstruera mer anställningslika förhållanden: systrarna fick under några år en fastställd lönesumma och kvalificerade sig därmed för en högre pension. ${ }^{580}$

Den ekonomiska gemenskapen i vardagen var en sak, men saken ställdes på sin spets när det gällde syskonens förhållande till fastigheten.

Oskar var näst yngst av tio syskon på ett litet östgötskt jordbruk. Efter att fyra lämnat hemmet och gift sig blev han tillsammans med fem syskon - två systrar och tre bröder - kvar på föräldragården. Hushållet hade en mycket sammansatt ekonomi, där fyra av syskonen delvis arbetade utanför hemmet med bland annat skogsarbete på ackord. När de yngsta var strax över trettio år bestämde sig de sex syskonen enligt Oskar för att inte gifta sig. För att säkra varand- 
ras ställning gentemot övriga syskon tecknade de tillsammans ett inbördes testamente, med innebörden att när en av dem dog skulle de kvarvarande ärva vederbörandes andel. ${ }^{581}$

Referatet aktualiserar frågan om förhållandet mellan samägande syskon och dem som en gång lösts ut från gården. Eftersom få hade egna bröstarvingar innebar ett dödsfall att arvslotten fördelades på efterlevande syskon med lika andelar. Risken var påtaglig för att de utflyttade syskonen eller deras bröstarvingar erhöll andelar i gården vid upprepade tillfällen. Ett enkelt räkneexempel illustrerar problemet: Ponera att det ursprungligen finns fyra syskon, gården delas lika mellan dem varpå ett löses ut medan övriga tre bor kvar. När ett av de kvarvarande syskonen dör delas hans eller hennes tredjedel på samtliga syskon, vilket innebär att den redan utlöste erhåller ytterligare en niondel av gården. Avlider ännu ett syskon på gården tillkommer två niondelar, och då har den utflyttade genom upprepade arv bekommit en lott motsvarande nära två tredjedelar av gården. Om arvingarna inte enades om att på ett eller annat sätt samäga fastigheten innebar det att de kvarboende kunde tvingas lösa in sina utflyttade syskon flera gånger. Utflödet av kapital från gården blir dessutom större ju högre andel av syskonen som lämnat densamma. I intervjuerna framgår att sådana upprepade inlösningar förekom i flera fall, och kravet att ånyo lösa in ett redan utköpt syskon kunde skapa frustration och missämja. ${ }^{582} \mathrm{I}$ ett fall vållade det svårigheter för resterande syskon att bo kvar på gården. ${ }^{583}$ Sett mot denna bakgrund är det inte förvånande att inbördes testamente mellan de kvarboende syskonen upprättades i flera fall. ${ }^{584}$

\section{Kontroverser}

Intervjuerna ger överlag en ljus bild av syskonjordbruket. Flera informanter berörde syskonens goda förhållande till varandra och att de på det stora hela tycktes vara nöjda med sina liv. Någon form av sammanhållning mellan syskonen var närmast en förutsättning för att de skulle förbli i samma hushåll, men det finns en risk att bilden är något förskönad, dels för att informanterna valde att inte 
berätta om mörkare sidor, dels för att de som hade kunskap om mer problematiska syskongårdar inte valde att anmäla sig som informanter. Det finns dock en handfull exempel på att syskonhushållet inte alltid var en dans på rosor.

Ainas far Vilhelm var gift och drev en gård i Blekinge. Formellt ägde han gården själv, men i hushållet ingick utöver hustru och barn även hans far och yngre bror Lars. Båda bröderna arbetade i jordbruket, men de stod inte på särskilt god fot med varandra. Lars fann sina egna sysslor och hade bland annat hand om traktorkörningen, emellanåt också åt andra bönder i trakten. Däremot vägrade han gå till ladugården. Sedan Vilhelm bildat familj försökte han förmå sin bror att flytta, bland annat genom att köpa en intilliggande villa som han erbjöd honom. Lars vägrade emellertid flytta och ansåg att det var som att "bli utkastad från sitt hem, han som slitit hela sitt liv för att hjälpa till". När Vilhelm så småningom beslöt att upphöra med jordbruket, arrendera ut marken och istället ta arbete på fabrik beättade han först inget för Lars, som först på omvägar fick veta att gården skulle börja brukas av andra. ${ }^{585}$

Beatas far var näst äldst av fyra bröder på ett familjejordbruk i Västerbotten, men han flyttade efter giftermål söderut i slutet av 1940-talet. Något år senare följde den äldre brodern honom i spåren. När den tredje brodern stod i begrepp att gifta sig och flytta uppmanade emellertid fadern den äldste brodern, som fortsatt var ogift, att återvända till gården eftersom den yngre inte skulle klara jordbruket själv. De två bröderna drev därefter jordbruket ihop, men situationen ändrades när den yngre gifte sig. Den ingifta hustrun ställde hårda krav och i spåren uppstod en rad konflikter mellan det gifta paret och den ogifte brodern. Trots att bröderna drev gården ihop och ägde den tillsammans förvägrades den äldre brodern bland annat att ha sin egeninköpta tvättmaskin i tvättstugan. Sina kläder fick han tvätta i ladugårdens mjölkrum. ${ }^{586}$

Annies far Birger var näst äldst av fem syskon, tre bröder och två systrar. Birger och den ena systern var de enda som gifte sig och läm- 


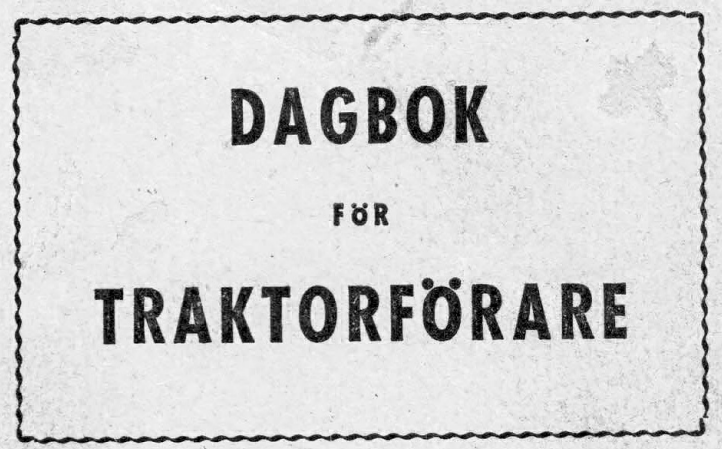

\begin{tabular}{|c|c|c|c|c|c|c|c|c|c|}
\hline \multirow{2}{*}{ Dag } & \multirow{2}{*}{$\begin{array}{c}\text { Skiftets nr eller } \\
\text { namn }\end{array}$} & \multicolumn{2}{|c|}{$\begin{array}{l}\text { Harvning } \\
\text { Vältning }\end{array}$} & \multicolumn{2}{|c|}{$\begin{array}{c}\text { Sådd } \\
\text { Hackrensn. }\end{array}$} & \multicolumn{2}{|c|}{$\begin{array}{l}\text { Slåster } \\
\text { Skörd }\end{array}$} & \multicolumn{2}{|c|}{ Plöjning } \\
\hline & & tim. & ha & tim. & ha & tim. & ha & tim. & ha \\
\hline
\end{tabular}

Septrang frears. sida

4 Plojde till vete och hóstade

5 ".."...". " halihsharvad

7 Rinqviltade och hóshade haves

8 Tioshade den sisha haven

9 Tallichsharade och rin yráltade

10 Hoide eeth kalkhoive och ord kraunen

II Tjiderharveh och stioff kalt

12 Solritshavade pó madex

19 Noide ulf kalte.

is " " "ock havade fill vetesid

16 Howade fill wete side rete sch ban

ix Plock ade de sisho quukorna

18 Kroide de fósta poritisen

2) " potalis pan maten

$2 \&$ " " " " "." "

29 " $" 1 . " 1$

24 " " " "

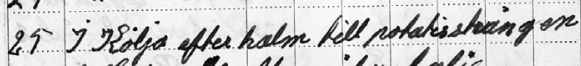
86 y Getorgate eftu saifratatis

Transp. till nästa sida

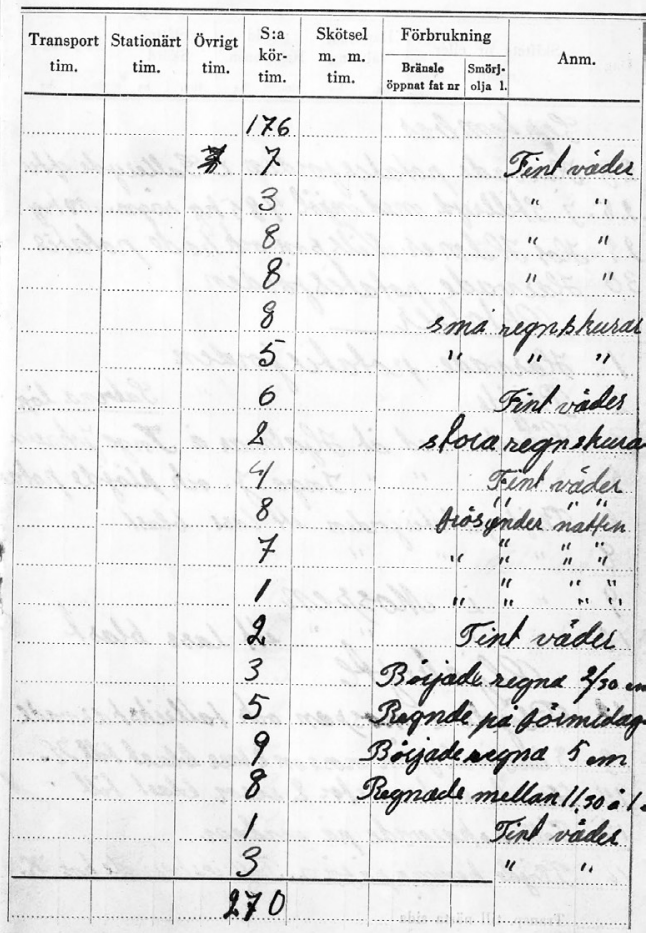

Traktorloggbok för den i texten nämnde Lars, september 1953. Som framgår tog traktorn en stor del av hans tid i anspråk. Loggboken innehåller noteringar för så gott som alla dagar utom söndagar. 
nade gården. Efter några år beslöt föräldrarna - utan att nämna saken för de utflyttade barnen - att sälja gården till de två hemmavarande sönerna. Den andra systern fick ingen del i gården men bodde kvar för att sköta brödernas hushåll. De två bröderna var dock väldigt olika och kom inte särskilt väl överens. Enligt Annie hade den äldre brodern läshuvud och ville egentligen inte bli jordbrukare, men han var äldst och skulle enligt föräldrarna därför överta vare sig han ville eller inte. Den yngre brodern var mer kunnig i jordbruket och hade särskilt god hand med djur. Efter några år gick det inte längre, den yngre brodern blev utköpt av den äldre och flyttade därifrån. ${ }^{587}$

Alla dessa tre konflikter försiggick mellan bröder. De två första förefaller ha härrört från svårigheter att förena syskonskap med äktenskap. Att denna kombination kunde skapa friktion framgick även i två av de fall där ett av syskonen var gift, även om konflikterna inte antog sådana proportioner som i referaten ovan. ${ }^{588}$ Konflikterna kunde röra sysslornas fördelning och investeringar men också hur det inre hushållet skulle fungera. Den tredje refererade konflikten tycks ha bottnat både i olika personligheter och förväntningar på vem som skulle överta gården. Enligt informanten var det för föräldrarna omöjligt att gå förbi den äldste sonen, trots att han hade ringa fallenhet för jordbruk. Att överföra gården på två bröder var ett sätt att kompromissa med traditionen, som dock inte föll väl ut.

Det kunde således förekomma oenighet mellan de samboende syskonen. Hur var det med sämjan med de syskon som flyttat ut från gården och lämnat gemenskapen? I intervjuerna framskymtar två olika mönster. I en handfull fall betraktades de som lämnat gården som svikare. En sådan schism kunde ha sin grund i olika val i dragkampen mellan att å ena sidan fullfölja plikter gentemot gården, syskonen och föräldrarna, och å andra sidan följa sitt hjärta i kärleksrelationer. I dessa konflikter var de främsta aktörerna kvinnor, både i rollen som de som kände sig svikna och de som ansågs ha svikit. ${ }^{59}$ Liknande schismer rörande utflyttade bröder saknas i materialet och en utflyttad bror kunde snarast få en något högre ställning än övriga syskon. ${ }^{590}$ Det andra mönstret var att gården fortsatte att utgöra en säkerhetslina för de utflyttade syskonen. Det 
kunde finnas ett ömsesidigt utbyte av arbetskraft och resurser mellan olika hushåll, och de kvarboende kunde bistå utflyttade som av ett eller annat skäl råkat i svårigheter. En utflyttad syster som blev lämnad ensam med flera små barn fick exempelvis försändelser med mat från gården för att klara sig. ${ }^{591}$ Därmed förstärks mönstret av ömsesidigt utbyte mellan syskonhushållet och de satellithushåll som de utflyttade syskonen utgjorde.

\section{Tillsammans från vaggan till graven}

I detta kapitel har jag med utgångspunkt i 29 intervjuer försökt teckna en bild av syskonhushållet inifrån, särskilt relationerna mellan hushållets medlemmar. Resultaten understryker hur sammansatt syskonjordbruket var som företeelse. Det är på det hela taget svårt att peka ut distinkta egenskaper. Gården kunde vara stor eller liten, jordbruket stagnerande eller expansivt, hushållen varierade i storlek och sammansättning och så vidare. Uppgifterna i detta kapitel förstärker därmed de resultat som framkommit i de tidigare. På ett par punkter har intervjuerna kastat ljus över förhållanden som inte kunnat studeras i tryckt material, och jag vill lyfta fram tre slutsatser.

För det första framträdde i intervjuerna att hushållsstrukturen kunde vara flytande. De sammanboende syskonen arbetade i huvudsak på jordbruket men kunde också ta arbeten utanför gården. Samtidigt förekom att syskon som flyttat fortfarande tog ett stort ansvar för arbetet på gården. Utbytet var ömsesidigt: syskonhushållet kunde bistå utflyttade syskon som hamnat i svårigheter, och försvann någon på hemmagården hände det att syskon återvände för att ta deras plats. Någon tydlig strävan att skapa en individuell sfär är också svår att spåra. Syskonen delade inte bara bostad och arbete utan ofta även sovrum och ekonomi. Systrarna var dock i mindre utsträckning delägare i fastigheterna och hade därmed ibland inte del i den gemensamma ekonomin. I en del fall hamnade de i en position mellan den egendomsägande familjen och anställd arbetskraft, vilket bland annat äventyrade deras framtida pension och sociala trygghet. 

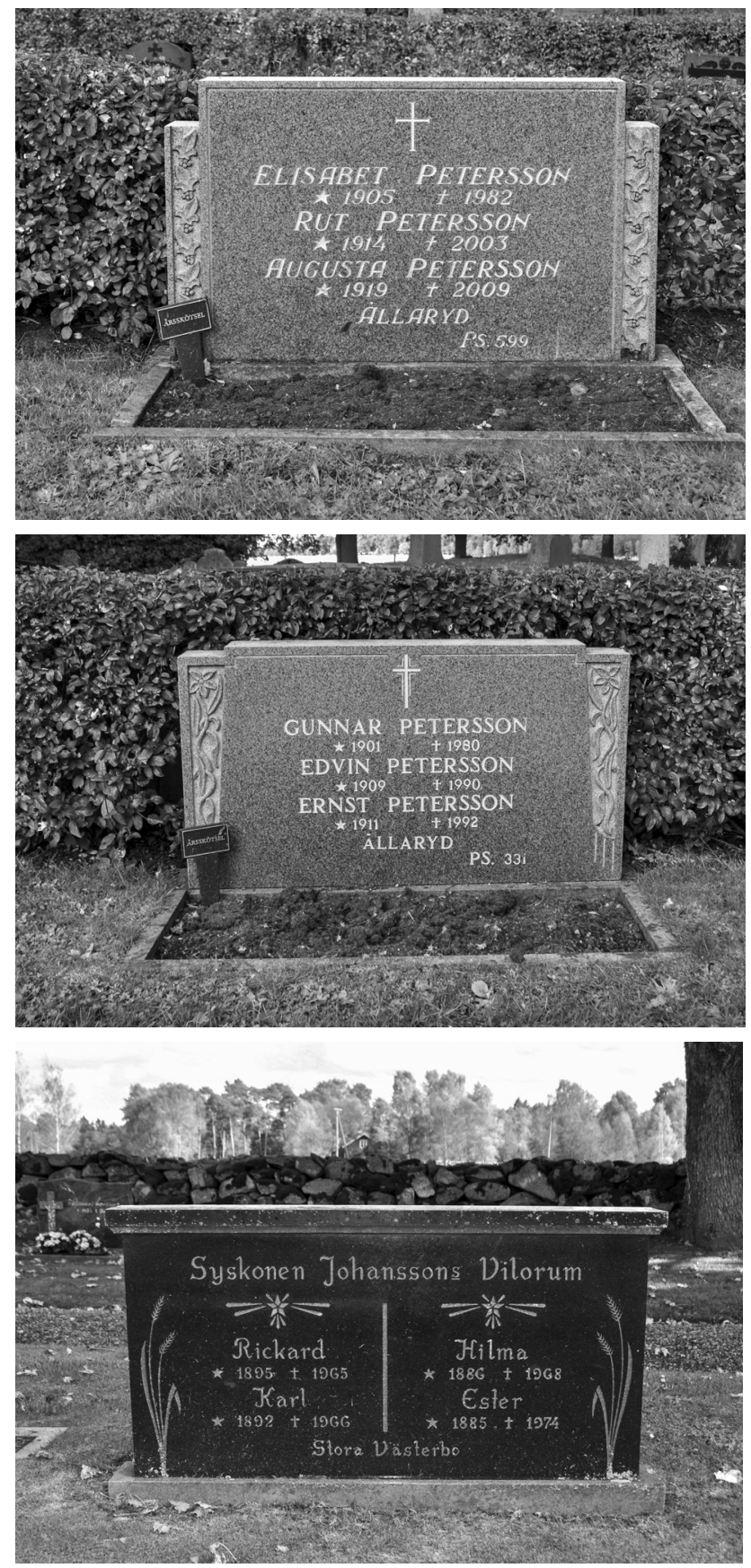

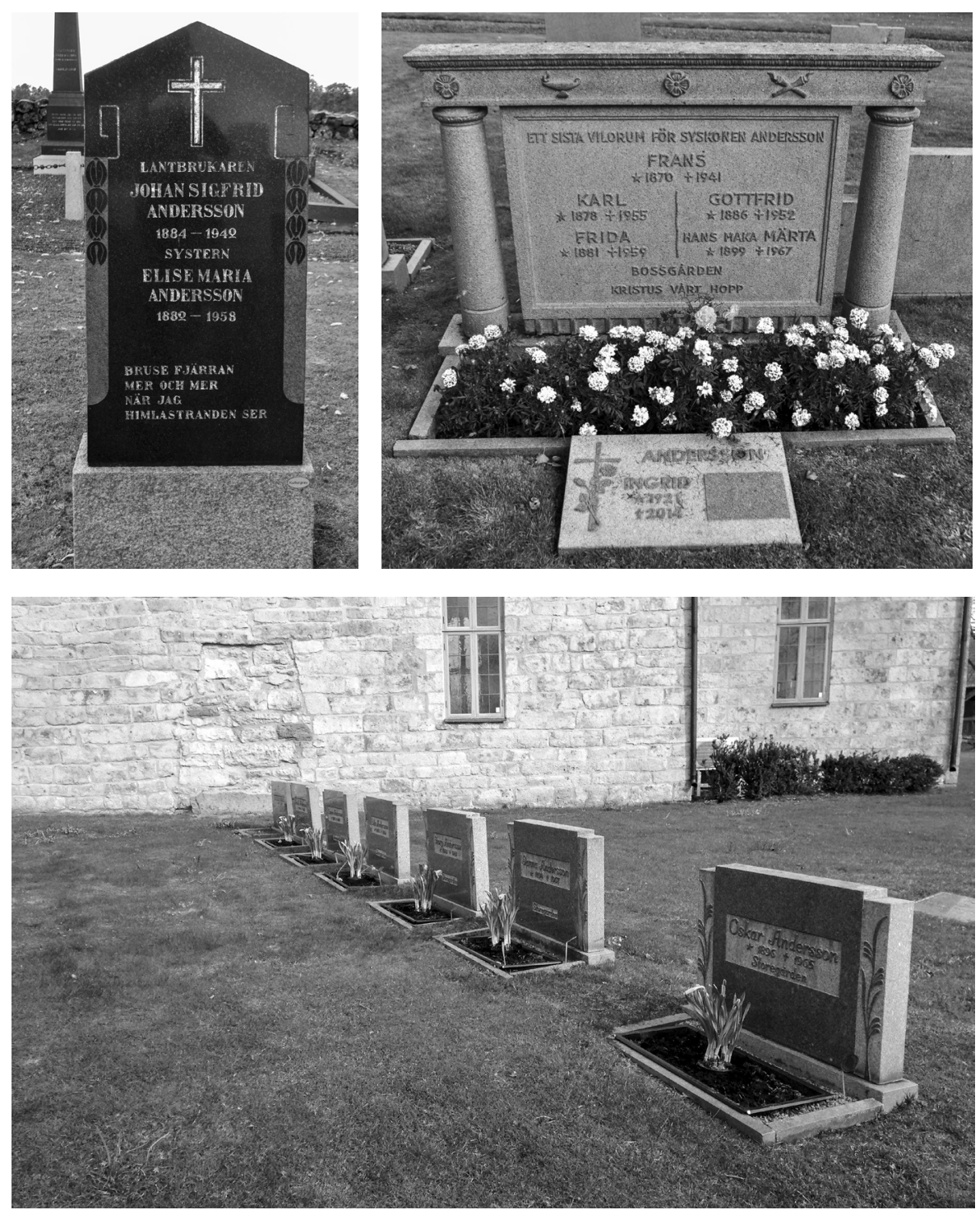

Ett av de få spår som i dag finns efter syskonjordbruken är deras gravvårdar. Sannolikt har många funnit sin sista vila i familjegravar, men det är inte särskilt svårt att finna syskongravvårdar. Ibland betonas syskonenheten, andra gånger är bröderna huvudpersoner och figurerar med yrkestitlar medan systrar inte blir mer än systrar. Ibland görs tydliga uppdelningar utifrån kön, andra gånger har varje syskon fått en identisk gravsten. I enstaka fall går det att finna mer komplicerade hushållskonstellationer, där även ingifta beretts plats. Syskongravvårdar från Göteve, Jäla, Jät och Kestad. Foto: Sara Roland (Kestad), författaren (övriga). 
För det andra visade intervjuerna på föräldrarnas tvetydiga roll i syskonjordbrukens etablering. Å ena sidan splittrades aldrig det ursprungliga hushållet utan generationerna fortsatte att leva tillsammans, vilket rimligen gjorde det svårare för arvingarna att bryta sig loss från gemenskapen. Många föräldrar vidtog heller inga åtgärder för att styra generationsskiftet. Det innebar dock inte att de avstod från att styra barnens livsval. Det var relativt vanligt att föräldrar utövade inflytande över sina barns äktenskapsplaner och kanske agerade för att ett äktenskap inte skulle komma till stånd, åtminstone inte med en ekonomiskt underlägsen partner. Det var ett öde som särskilt drabbade kvinnor och kan sannolikt kopplas till behovet av arbetskraft i hemmet. Å andra sidan visar intervjuerna att många dödsfall i föräldragenerationen inträffade medan barnen ännu var relativt unga, vilket medförde att de tvingades ta föräldrarnas plats i arbetet och hushållet. Det kunde säkerligen svetsa samman syskonskaran och även här förefaller döttrarna ha fått dra ett tungt lass för att hålla hushållet på fötter, särskilt om flera av syskonen var minderåriga.

För det tredje framskymtade i materialet att relationerna mellan syskonen kunde vara ansträngda. Spänningarna kunde ta sig olika uttryck. Ofta hade de sin grund i att någons handlingar inte uppfyllde förväntningarna. Att bryta sig loss ur hushållet kunde ses som en osolidarisk handling. De största spänningarna låg dock i förhållandet mellan syskonskap och äktenskap. Mycket få av syskonjordbrukarna gifte sig, och då främst på enkönade gårdar, vilket överensstämmer med resultatet i föregående kapitel. Men de många uteblivna äktenskapen innebar inte att kärleksaffärer saknades. När sådana belystes i intervjuerna framgick dock tydligt svårigheterna att kombinera äktenskapet med ett jordbruk baserat på samboende syskon. 